\title{
Supporting girls in their transition to secondary education: An exploratory study of the family, school and community environments of adolescent girls in Gujarat
}

\author{
K.G. Santhya \\ Population Council \\ Shireen J. Jejeebhoy \\ Population Council \\ A.J. Francis Zavier \\ Population Council \\ Rajib Acharya \\ Population Council \\ Neeta Shah
}

Follow this and additional works at: https://knowledgecommons.popcouncil.org/departments_sbsr-pgy

Part of the Demography, Population, and Ecology Commons, Family, Life Course, and Society Commons, and the International Public Health Commons

How does access to this work benefit you? Let us know!

\section{Recommended Citation}

Santhya, K.G., Shireen J. Jejeebhoy, A.J. Francis Zavier, Rajib Acharya, and Neeta Shah. 2014. "Supporting girls in their transition to secondary education: An exploratory study of the family, school and community environments of adolescent girls in Gujarat." New Delhi: Population Council. 

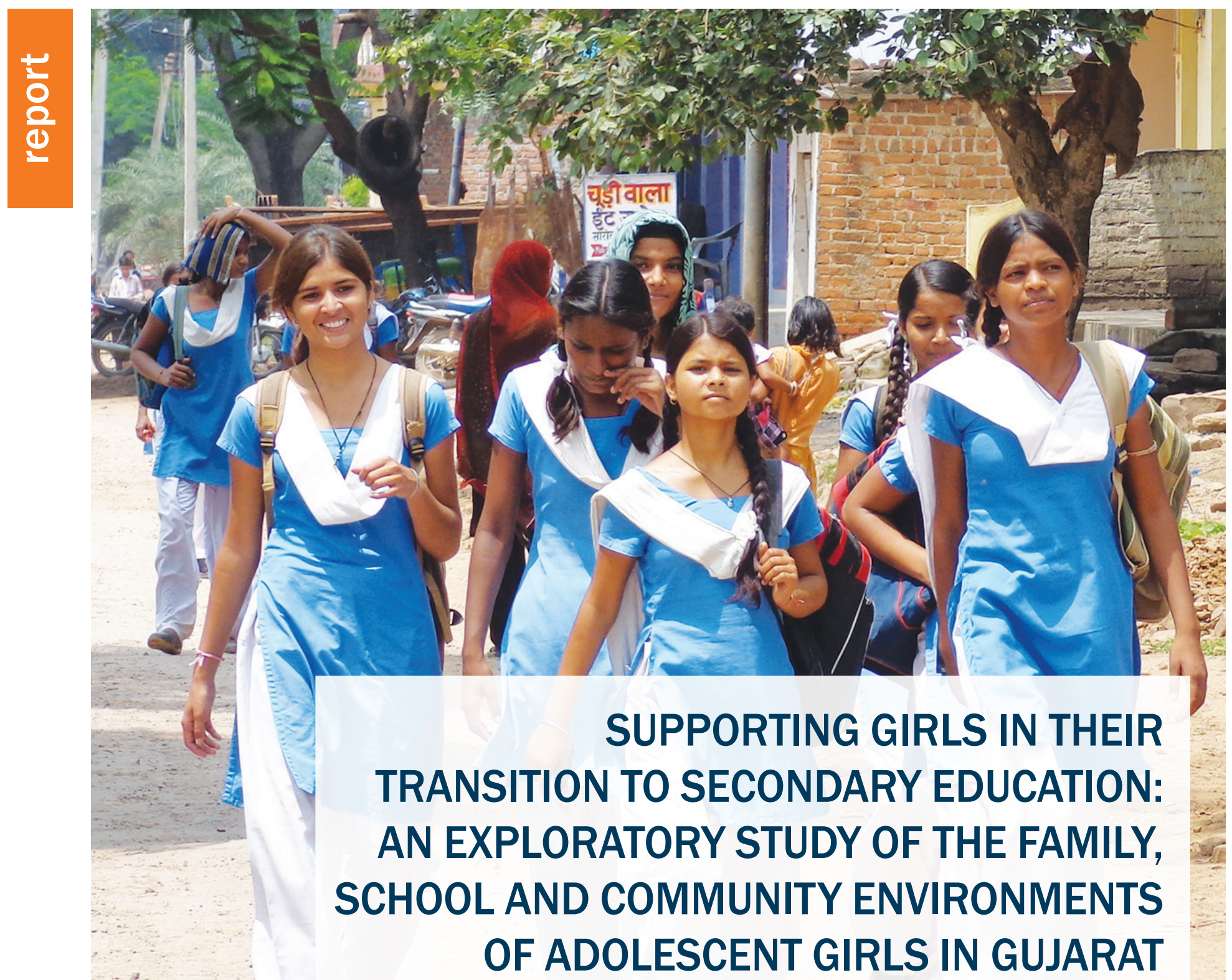

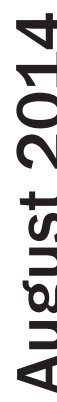

\section{POPULATION COUNCIL}

Ideas. Evidence. Impact.

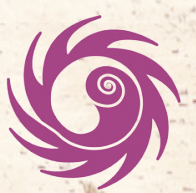

CHETVA

For Women Young people Children 


\section{POPUlATION COUNCIL}

Ideas. Evidence. Impact.

The Population Council confronts critical health and development issues-from stopping the spread of HIV to improving reproductive health and ensuring that young people lead full and productive lives. Through biomedical, social science, and public health research in 50 countries, we work with our partners to deliver solutions that lead to more effective policies, programs, and technologies that improve lives around the world. Established in 1952 and headquartered in New York, the Council is a nongovernmental, nonprofit organization governed by an international board of trustees.

\section{Population Council}

Zone 5A, Ground Floor

India Habitat Centre, Lodi Road

New Delhi, India 110003

Phone: 91-11-24642901

Email: info.india@popcouncil.org

Website: www.popcouncil.org

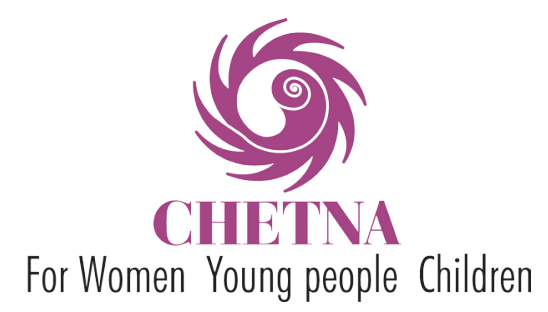

Center for Health, Education, Training and Nutrition (CHETNA) as a resource organisation contributes towards empowering children young people and women especially from marginalized social groups to take control of their own their families' and communities' health.

\section{CHETNA}

Supath-II, B-Block,

3rd Floor, Opp. Vadaj Bus Terminus

Ashram Road, Vadaj

Ahmedabad-380013.

Phone: 91-079-27559976/77

Email: chetna456@gmail.com

Website: www.chetnaindia.org

Suggested Citation: Santhya, K. G., S. J. Jejeebhoy, A. J. Francis Zavier et al. 2014. Supporting Girls in Their Transition to Secondary Education: An Exploratory Study of the Family, School and Community Environments of Adolescent Girls in Gujarat. New Delhi: Population Council. 


\title{
SUPPORTING GIRLS IN THEIR TRANSITION TO SECONDARY EDUCATION: AN EXPLORATORY STUDY OF THE FAMILY, SCHOOL AND COMMUNITY ENVIRONMENTS OF ADOLESCENT GIRLS IN GUJARAT
}

\author{
K G Santhya \\ Shireen J Jejeebhoy \\ A J Francis Zavier \\ Rajib Acharya \\ Neeta Shah
}
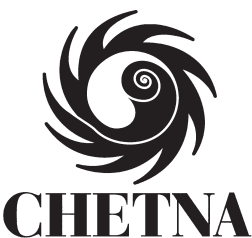

For Women Young people Children 


\section{Table of Contents}

List of Tables $\quad$ V

$\begin{array}{ll}\text { Acknowledgements } & \text { vii }\end{array}$

Chpater 1 Introduction 1

Chpater 2 School experiences of girls 8

Chpater 3 Girls' future aspirations, agency, gender role attitudes and time use 13

Chpater 4 School environment of adolescent girls 20

Chpater 5 Parental and community engagement in girls' education 28

Chpater $6 \quad$ Summary and conclusions 35

Annexure 1 Details of the household wealth index 40

$\begin{array}{ll}\text { References } & 41\end{array}$ 


\section{List of Tables}

Table 1.1: $\quad$ Selected characteristics of the study district and state

Table 1.2: Selected socio-demographic characteristics of surveyed girls and their parent

Table 1.3: Selected socio-demographic characteristics of girls who participated in the survey

Table 2.1: Girls' school attendance during the current academic year

Table 2.2: $\quad$ Percentage of girls who missed school by reasons for absence

Table 2.3: Girls' academic performance in selected subjects

Table 2.4: Girls'academic performance by school attendance

Table 3.1: Percent distribution of girls by their aspirations about their education and career

Table 3.2: $\quad$ Percentage of girls displaying the ability to perform well at school

Table 3.3: Percent distribution of girls by educational level they expected to attain under their current circumstances and percentage perceiving inability to attain aspired level by reasons

Table 3.4: Percentage of girls displaying agency

Table 3.5: Percent distribution of girls by perceptions about the ideal level of education for girls and boys

Table 3.6: Percentage of girls reporting that boys and girls should complete at least Class 10 by reasons

Table 3.7: Gender egalitarian attitudes of girls

Table 3.8: $\quad$ Time use pattern of girls

Table 4.1: $\quad$ Percentage of girls reporting physical access to school

Table 4.2: Percentage of girls reporting the availability of selected items of infrastructure and number of teachers in their school

Table 4.3: Percentage of girls who were aware of entitlements from school

Table 4.4: Percentage of girls who had received their entitlements during the current academic year

Table 4.5: Percentage of girls who had received scholarships during the current academic year by caste and household economic status 
Table 4.7: $\quad$ Percentage of girls reporting that their teachers displayed positive, respectful, non-discriminatory and gender egalitarian attitudes and practices, in the week preceding the interview

Table 4.8: Percentage of girls reporting experience of corporal punishment, verbal harassment or sexual harassment perpetrated by their teacher, in the week preceding the interview

Table 4.9: Percentage of girls performing non-academic tasks in school, in the week preceding the interview

Table 4.10: Percentage of girls reporting access to a trusted adult at school to discuss personal problems and having solicited advice

Table 4.11: Percentage of girls reporting teasing or harassment by fellow male students in their class/school, in the week preceding the interview

Table 5.1: $\quad$ Percent distribution of girls by perceived parental aspirations about their education and career

Table 5.2: $\quad$ Percentage of girls reporting their parents' awareness of student entitlements

Table 5.3: Percentage of girls who reported discussing studies with their parents, in the week preceding the interview, by topic of discussion

Table 5.4: $\quad$ Percentage of girls reporting that their parents spent time with them on their studies in the week preceding the interview, by type of support received

Table 5.5: Percentage of girls reporting that their parents had visited their school, in the month preceding the interview, by purpose of visit

Table 5.6: Percentage of girls reporting financial investments by parents in their education in the month preceding the interview, by item of expenditure

Table 5.7: $\quad$ Percent distribution of girls by awareness of school management committees

Table 5.8: Percent distribution of girls by perceived engagement of panchayat members in promoting girls' education 


\section{Acknowledgements}

This study has benefited immeasurably from the inputs of many. We are extremely grateful to the John D. and Catherine T. MacArthur Foundation and the Human Dignity Foundation for their financial support which made this study possible.

We could not have successfully completed this study without the support of the Education Department, Government of Gujarat. We would like to acknowledge with gratitude the support that we received from Shri. J. G. Pandya, District Education Officer, and Shri. P. S. Parghi, District Primary Education Officer, Surendranagr district, Gujarat. We would also like to acknowledge the contribution of various officials of the Education Department at the block level in Surendranagar District, principals and other teachers of the primary and secondary schools in the villages in which the survey was conducted.

We are grateful to Dr. Leela Visaria, Honorary Professor, Gujarat Institute of Development Research, Ahmedabad for reviewing the earlier draft of this report and providing insightful comments and suggestions.

At the Population Council, several colleagues have supported us in both the technical and administrative aspects of this study. We are grateful to Barbara Mensch and Cynthia B Lloyd for reviewing the study protocol as well as the earlier draft of this report, and for giving valuable comments and suggestions. We would also like to thank M.A. Jose for ably managing the administrative aspects of the project, Shilpi Rampal for her support with data management and Komal Saxena for ably coordinating the printing of the report. We would like to thank Jyoti Moodbidri and Komal Saxena for their editorial contributions. We also appreciate the efforts of our investigators who painstakingly collected the data.

At CHETNA too, several colleagues have supported the study; we are grateful to Pallavi Patel for her support for the study.

Finally, and most importantly, we would like to thank the adolescent girls who generously gave us their time and shared their views and experiences with us.

K. G. Santhya

Shireen J. Jejeebhoy

A.J. Francis Zavier

Rajib Acharya

\section{Population Council}

Neeta Shah

CHETNA 


\section{Chapter 1 Introduction}

\section{Background and rationale}

Despite government commitment to universal secondary education, few adolescents transition to and successfully complete secondary education in India. Just 42 percent of young men and 32 percent of young women aged 18-24 had completed Class 10, the final year of (lower) secondary school, in 2005-06 (International Institute for Population Sciences and Macro International, 2007). Recent data on gross enrolment ratios (GERs) show that in 2010-11, GERs in Classes $6-8$ were 88 percent and 83 percent among boys and girls, respectively; the corresponding GERs in Classes 9-10 were 69 percent and 61 percent, respectively (Ministry of Human Resource Development, 2014). As observed by the Working Group on Secondary and Vocational Education for the XIIth Five Year Plan, an underlying issue is the limited evidence on best and innovative practices to promote secondary education (Ministry of Human Resource Development, 2011a). Specific to the transition of girls to secondary education, the Working Group reports that the lack of adequate community mobilisation activities has been a major impediment to the success of schemes intended to promote the secondary education of girls.

The importance of mobilising communities, especially parents, in encouraging girls to transition to and successfully complete secondary education is evident from data suggesting that among several reasons inhibiting the transition of adolescents from primary to secondary school, perhaps the most prominent is parental perceptions about the value and relevance of secondary education for their children, particularly daughters (International Institute for Population Sciences and Population Council, 2010). Global evidence, albeit limited, also argues for raising parental awareness about the returns to education and ensuring parental accountability for education. For example, a study conducted in the Dominican Republic found that providing eighth grade students with information on differences in earnings by years of schooling led to reduced dropout rates in the subsequent year and increased school completion four years later (Jensen, 2010). Another study in Madagascar found that providing information to fourth grade students and their parents about differences in earnings by educational level increased average attendance and test scores (Nguyen, 2008). Moreover, recent evidence from a comparative cost-effectiveness analysis of eleven programmes to improve school attendance in developing countries found that raising awareness among parents on returns to education was more cost-effective in terms of additional years of student participation per dollar spent than other interventions such as de-worming, free uniforms, monitoring of teachers' attendance, computer-assisted learning curriculum, remedial tutoring and conditional cash transfers (Dhaliwal et al., 2011). Likewise, a synthesis of intervention models supporting the education of adolescent girls in developing countries reports that best or promising demand-side strategies include providing scholarships and stipends, facilitating transportation and providing boarding facilities, enhancing school safety and promoting community engagement (Lloyd, 2009). These studies clearly point to the importance of efforts to change parental and community perceptions about the value of educating girls.

In India, however, limited efforts have been directed at parents to promote positive attitudes toward education and school completion; raise their aspirations about their children's education, especially their daughters' education; and encourage greater parental involvement in their children's education. While some intervention models to engage parents and communities have been attempted, these have focused on promoting primary rather than secondary education (Banerjee et al., 2006; 2010; Pandey, Goyal and Sundararaman, 2009). At the same time, the policy and programme environment is conducive for testing models to promote parental and community engagement and accountability in secondary education for girls. For example, the XIlth Five-Year Plan seeks to increase access to secondary and higher education, ensure equity, improve the quality of inputs and outcomes, and promote greater governance and accountability (Planning Commission, 2013). The recently launched National Youth Policy 2014 notes that youth must have equitable access to high quality education and be able to develop the skills that are required by the labour market to ensure that they are gainfully employed (Ministry of Youth Affairs and Sports, 2014).

Recognising the need for identifying feasible and effective intervention strategies to engage parents and communities to promote secondary education for girls, with a special focus on completion of at least Class 10 , 
the Population Council, in partnership with CHETNA, MV Foundation, Awaaz.De and Navjeevan Trust, and with the support of the John D. and Catherne T. MacArthur Foundation and the Human Dignity Foundation, is currently pilot testing an intervention to support adolescent girls' transition to and retention in secondary education as also to improve their learning outcomes by building parental and community engagement in and accountability for secondary education. Specifically, the objectives of the project are: (1) to raise awareness among adolescent girls, their parents and other community members about the economic and social returns to secondary education for girls and strengthen parents' commitment to secondary education for their daughters, (2) to provide parents with information and support in overcoming bureaucratic and logistical barriers, including transportation barriers, that prevent many girls from pursuing secondary education, and (3) to enhance communication and interaction between girls, their parents and their teachers to enable more accountability for girls' education.

Located in the state of Gujarat, the intervention focuses on girls who are in the last year of primary school (Class 8) and the first year of secondary school (Class 9) and their parents as well as teachers in primary and secondary schools, and the wider community, notably village leaders and elected representatives. The school experiences of adolescent girls, and the family, school and community environments in which they are pursuing their studies, described in this report, draw on a baseline survey conducted in 90 villages, selected for locating the study, in four blocks of Surendranagar district in Gujarat.

\section{Objectives}

The objective of the study was to explore the school experiences of adolescent girls in the last year of primary school and the first year of secondary school, that is, in Classes 8 and 9, respectively, and to assess the extent to which a supportive environment for schooling was available to them at the family, school and community levels. Specifically, the study sought to understand from girls who participated in the survey:

- their experiences in school, including their class attendance and academic performance;

- their educational aspirations and agency in matters related to schooling;

- the extent to which a supportive environment was available in their school;

- the extent to which their family environment was supportive of their schooling; and

- their perceptions about community support for their schooling.

\section{Study setting}

The study was conducted in the rural areas of Surendranagar district in Gujarat. Gujarat, the tenth largest among the 30 states of India, has a population of 60 million of which 20 percent are adolescents aged 10-19 years (Office of the Registrar General and Census Commissioner, India, 2013; 2014). Its population continues to be characterised by population and child sex ratios unfavourable to females. A substantial proportion of households in the state belong to socially excluded castes, namely, scheduled castes and tribes (30\% in rural areas) (Office of the Registrar General and Census Commissioner, India, 2013). Gujarat is among the economically progressive states in the country, ranked fifth among states of India in terms of gross state domestic product and in 2011-12, it accounted for seven percent of the national GDP (Ministry of Statistics and Programme Implementation, 2012); even so, 27 percent of its rural population was estimated to live below the poverty line in 2009-10 (Planning Commission, 2012). In 2011, the overall literacy rate was 72 percent in rural Gujarat, compared to 68 percent nationally in rural areas (Office of the Registrar General and Census Commissioner, India, 2013); gender differences were, however, considerable: 82 percent of rural males, compared to 61 percent of rural females, were literate. Three-fifths (59\%) of the state's rural households had access to a mobile or landline phone (Office of the Registrar General and Census Commissioner, India, 2012).

Access to primary education (Classes 1-8) is more or less universal and most children aged 6-14 years are enrolled in school in Gujarat as elsewhere in India. A 2011 survey reports that only three percent of girls and boys aged 6-14 years were not enrolled in school in rural Gujarat (ASER Centre, 2012). However, a substantial proportion of adolescents, considerably more girls than boys, do not progress to secondary school: 67 percent and 52 percent of adolescent boys and girls, respectively, were enrolled in secondary school (Classes 9-10) in 2009-10 (Ministry of 
Human Resource Development, 2011b). The state has a gender parity index of 0.77 in Classes 9-10, compared to 0.88 nationally.

Many programmes have been implemented across the state that are likely to have long-term effects on educational outcomes for adolescent girls. These measures include the Rashtriya Madhyamik Shiksha Abhiyan (the scheme for universalisation of secondary education); the establishment of model schools; the promotion of information and communication technology in schools; the provision of scholarships and stipends as well as financial incentives to girls, for example, the Vidyalaxmi Bond scheme (under which each girl whose parents belong to the lower income groups is given a bond of the value of Rs. 2,000 when the girl takes admission in secondary school, that is, in Class 9) and the Vidyadeep Insurance Scheme (under which all students in Classes 8-12 are insured against mishaps and natural calamities that may occur during school hours). Plans are underway to establish secondary (Classes 8-10) and higher secondary schools (Classes 11-12) within five and 7-10 kilometres, respectively, of any habitation; ensure universal access to secondary education by 2017 and universal retention by 2020; and make special efforts to ensure that disadvantaged groups, including girls, are not deprived of secondary education (Ministry of Human Resource Development, 2009b).

Surendrangar is among the districts of Gujarat that are characterised by high levels of school discontinuation among girls who complete their primary education. Data from a District Level Household Survey conducted in 2007-08 show that the transition rate from Class 8 to Class 9 among girls aged 14-17 years was only 59 percent (International Institute for Population Sciences, 2010). Sizeable proportions of the district's rural population are poor, educationally disadvantaged and socially excluded: in 2007-08, 18 percent of households were economically poor and 24 percent did not have a single literate adult member (International Institute for Population Sciences, 2010); moreover, in 2011, 11 percent belonged to socially disadvantaged caste groups (Office of the Registrar General and Census Commissioner, n.d. a). At the same time, district data show that 69 percent of rural households had access to a mobile (67\%) or landline phone (2\%) in 2011 (Office of the Registrar General and Census Commissioner, n.d. b).

As mentioned earlier, the study was located in the rural areas of Surendranagar district. Four of the ten blocks in the district were selected for the study such that their socio-demographic indicators namely, female literacy rate, population belonging to socially disadvantaged caste groups (that is, scheduled castes and tribes) and population engaged in non-agricultural activities were similar to the corresponding district averages. A few key indicators of the study district and state are presented in Table 1.1.

Table 1.1: Selected characteristics of the study district and state

\begin{tabular}{|c|c|c|c|c|}
\hline \multirow[b]{2}{*}{ Characteristics } & \multicolumn{2}{|c|}{ Gujarat } & \multicolumn{2}{|c|}{ Surendranagar } \\
\hline & Total & Rural & Total & Rural \\
\hline Total population ${ }^{a}$ & $60,439,692$ & $34,694,609$ & $1,756,268$ & $1,259,352$ \\
\hline$\%$ rural population ${ }^{a}$ & 57.4 & - & 71.7 & - \\
\hline$\%$ population in the adolescent age group (10-19 years) ${ }^{b}$ & 19.9 & 20.7 & 21.5 & 22.1 \\
\hline Child sex ratio $^{a}$ & 890 & 914 & 896 & 906 \\
\hline Female literacy rate (population aged $7+$ years) ${ }^{a}$ & 69.7 & 61.4 & 61.5 & 56.1 \\
\hline$\%$ population belonging to socially excluded castes/groups ${ }^{a}$ & 21.5 & 29.7 & 11.4 & 11.7 \\
\hline$\%$ population engaged in non-agricultural activities ${ }^{a}$ & 23.7 & 12.8 & 17.6 & 10.6 \\
\hline
\end{tabular}

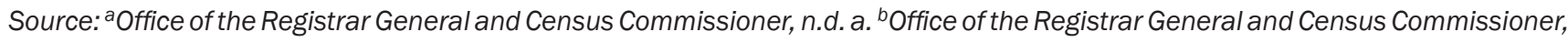
n.d. c.

\section{Study design}

A randomised controlled trial (RCT) with a cluster design was proposed to evaluate the intervention. Within each selected block, we mapped all the villages and created clusters, with each cluster containing five geographically contiguous villages and at least one secondary school. ${ }^{1}$ Villages that shared a common boundary with these clusters were excluded to minimise contamination between intervention and control clusters. Thus, 18 clusters, consisting of

${ }^{1}$ Of the 18 clusters, 15 clusters contained one secondary school each, and the remaining three clusters contained two secondary schools each. 
90 villages, were created within the four blocks, ${ }^{2}$ and were randomised into intervention and control clusters using a restricted randomisation strategy. Specifically, we generated all possible combinations in which these clusters could be assigned to two study arms, resulting in 48,620 combinations to select from. A host of factors such as the percentage of the population belonging to socially excluded castes or tribes, female literacy, teacher-student ratio in secondary schools and distance to the secondary school were considered for ensuring that the two study arms were similar in terms of these characteristics. The combinations that did not meet our restriction criteria-the difference between intervention and control arms should not exceed 5 percent in respect of the percentage of population belonging to scheduled castes or tribes and female literacy rate; should not exceed 10 in respect of the number of students per teacher (teacher/student ratio); and should not exceed 5 kilometers-in respect of the average distance to a secondary school-were excluded from the total combinations; some 32,232 combinations were thus removed. From the remaining combinations, we then selected one using a random number. Of the two arms of the selected combination, we randomly assigned one to serve as the intervention arm and the other to serve as the control arm.

A baseline pre-intervention survey of all the girls attending Class 8 and Class 9 residing in the 90 villages comprising the 18 clusters was conducted. We identified girls studying in Class 8 and Class 9 through a rapid listing of all the households in these villages. A total of 26,868 households were listed. During the household listing, the field team first enquired about girls aged 10 to 18 years residing in the household from an adult member of the household. For each of these girls thus listed, the team collected information about her name, age, marital status, highest class successfully completed, the year in which she completed the last class successfully, whether she was currently studying and if yes, the class she was currently attending, the name of the school she was attending and the name of the village in which the school is located. The team also collected the names of the parents of these girls and their mobile/landline phone number(s). All the girls who were studying in Class 8 and Class 9 thus identified, numbering 1,008 and 560, respectively, were invited to take part in the survey.

\section{Study instrument}

Two questionnaires were developed-a questionnaire to collect household-related information and a questionnaire to elicit information from girls. Responses to the household questionnaire were obtained from a responsible adult member of the household to which the eligible girl belonged. The household questionnaire collected information about the basic socio-demographic characteristics of the household and access to various amenities.

The girl's questionnaire sought information on her educational aspirations and expectations; her agency, gender role attitude and time use; her experiences at school, including attendance as also her perceptions about teacher attitudes, practices and attendance; facilities and environment in the school; her awareness of and utilisation of entitlements from school, her access to safe transportation to commute to school; and her perceptions of her parents' aspirations about and support for her education, and of community engagement in the education of girls. We also administered competency tests in the English and Gujarati languages, and in Mathematics to assess the academic performance of the girls.

The questionnaires were translated into Gujarati, pre-tested and revised in light of the insights obtained during pre-testing.

\section{Recruitment, training and fieldwork}

A total of 22 young women and men underwent training for undertaking household mapping and 29 young women for administering the survey instrument to the girls who participated in our survey. These research assistants are graduates in science or social science streams, are proficient in Gujarati and have 3-4 years of experience in conducting field-based studies. The training team monitored each trainee's progress on a regular basis and selected as interviewers only those trainees who demonstrated a full understanding of the questionnaire as well as the ability to ask questions appropriately and record responses accurately. Thus, 18 young women and men were selected for household mapping and 12 young women for the girls' survey.

The training of interviewers was conducted by Population Council staff in partnership with CHETNA staff. The training duration for household mapping and the girls' survey was two days and one week, respectively. Moreover, to ensure

${ }^{2}$ Each of the four blocks contained $4-5$ clusters. 
data quality and adherence to ethical principles, Council staff provided on-going supervision and support to the interviewers. Data collection was undertaken in August and September 2013.

A total of 999 out of 1,008 Class 8 girls and 559 out of 560 Class 9 girls successfully completed the survey. We note that the number of girls identified was smaller than estimated. A range of reasons have been suggested for the smaller than estimated number of girls found in these villages-seasonal migration of the families, girls residing in hostels outside the study blocks/district, and even deliberate withholding of information by parents about girls who have been withdrawn from school.The response rates were 99 percent and 100 percent for Class 8 and Class 9 girls, respectively. The remaining girls could not be interviewed as they were not available in the village even after making three visits.

\section{Characteristics of respondents and their parents}

Table 1.2 presents a profile of the adolescent girls who participated in the survey and their parents. On average, Class 8 girls were aged 12.5 years (with a standard deviation of 0.7 ) and Class 9 girls were almost one year older (13.4 years with a standard deviation of 0.7 ), suggesting that most girls had enrolled in school at the right age and had not repeated any class.Over 90 percent of the girls, regardless of the class they were attending, were Hindus; the remaining girls were Muslims. Distribution by caste shows that, in general, the majority of girls were from other backward castes (66\% and $62 \%$ of Class 8 and Class 9 girls, respectively).

A sizeable proportion of the girls had been engaged in either paid or unpaid work in the week prior to the interview as well as during the last vacation. Specifically, 32 percent of Class 8 girls and 29 percent of Class 9 girls had been so engaged, with involvement in unpaid work being more common than in paid work (27\% versus $6 \%$ among Class 8 girls and 25\% versus $8 \%$ among Class 9 girls). Further, a little over one-quarter of the girls had been engaged in such activities away from home (30\% among Class 8 girls and 27\% among Class 9 girls); this implies that over 90 percent of all those who had worked in the week prior to the interview had worked away from home. However, only a small minority of the girls had been involved in these activities throughout the week prior to the interview (4\% of Class 8 girls and $2 \%$ of Class 9 girls). The findings also show that involvement in paid or unpaid work was more widespread during school vacations than during school days; almost one-half (48\%) of both Class 8 and Class 9 girls reported that they had been so engaged during the last school vacation. While unpaid work predominated (38\% and 36\% among Class 8 and Class 9 girls, respectively), notable percentages of girls had been engaged in paid work as well during their vacation (21\% of Class 8 girls and $26 \%$ of Class 9 girls). Most girls had been engaged in these activities away from home (46\% each of Class 8 and Class 9 girls), and about $7-8$ percent had been involved in such activities throughout their last vacation.

Exposure to mass media was observed to be widespread among girls in the study settings. For example, 95 percent and 93 percent of Class 8 and Class 9 girls, respectively, reported that they had watched television and 82 percent and 80 percent, respectively, had read newspapers, magazines or books other than school textbooks sometimes or often in the month preceding the interview. However, only a small minority of the surveyed girls had listened to the radio $(7-8 \%)$ or accessed the internet (1-2\%) during this period.

The economic status of the household was measured using an index, composed of household asset data on ownership of selected durable goods, including means of transportation as well as access to a number of amenities. The wealth index was constructed by allocating scores to a household's reported assets or amenities (for details of the scores, see Annexure 1). Index scores, so constructed, ranged from 0 to 52 . The majority of the girls came from middle-income households (mean score of 24 on a scale that ranged in value from 0 to 52 ).

Almost all the girls who took the survey reported that both their parents were surviving (95-96\%) and that they were co-residing with their parents (94-96\%). The median number of years of education completed by their fathers was higher than that completed by their mothers-seven years versus none among Class 8 girls and seven years versus three years among Class 9 girls. On average, girls reported 1.4 brothers and 1.4-1.5 sisters, regardless of the class in which they studied. 
Table 1.2: Selected socio-demographic characteristics of surveyed girls and their parents

\begin{tabular}{|c|c|c|}
\hline Characteristics & Class 8 girls & Class 9 girls \\
\hline \multicolumn{3}{|l|}{ Age (years) } \\
\hline Mean & $12.5 * * *$ & 13.4 \\
\hline \multicolumn{3}{|l|}{ Religion (\%) } \\
\hline Hindu & 94.3 & 94.6 \\
\hline Muslim & 5.7 & 5.4 \\
\hline \multicolumn{3}{|l|}{ Caste/tribe (\%) } \\
\hline Scheduled castes or tribes & $17.2^{*}$ & 22.6 \\
\hline Other backward castes & 65.5 & 61.6 \\
\hline General castes 1 & 17.3 & 15.8 \\
\hline \multicolumn{3}{|l|}{ Engagement in work in the week prior to the interview (\%) } \\
\hline Engaged in paid or unpaid work & 31.6 & 29.4 \\
\hline Paid work & 6.4 & 7.7 \\
\hline Unpaid work & 27.4 & 24.6 \\
\hline Engaged in work away from home & 29.7 & 27.3 \\
\hline Engaged in work throughout the week prior to the interview & 3.9 & 2.2 \\
\hline \multicolumn{3}{|l|}{ Engagement in work during the last school vacation (\%) } \\
\hline Engaged in paid or unpaid work & 47.8 & 48.1 \\
\hline Paid work & $20.7 *$ & 25.6 \\
\hline Unpaid work & 38.4 & 35.9 \\
\hline Engaged in work away from home & 45.7 & 46.4 \\
\hline Engaged in work throughout the last vacation & 8.2 & 7.3 \\
\hline \multicolumn{3}{|c|}{ Exposure to mass media in the month preceding the interview (\%) } \\
\hline Watched television & 95.4 & 93.3 \\
\hline Read newspapers/ magazines/ non textbooks & 81.8 & 79.9 \\
\hline Listened to radio & 7.1 & 7.5 \\
\hline Accessed internet & 1.4 & 1.9 \\
\hline \multicolumn{3}{|l|}{ Household economic status } \\
\hline Mean score, wealth index (0-52) & 24.0 & 24.1 \\
\hline \multicolumn{3}{|l|}{ Survival status of parents (\%) } \\
\hline Both parents dead & 0.3 & 0.0 \\
\hline Only father alive & 1.8 & 1.7 \\
\hline Only mother alive & 1.8 & 3.2 \\
\hline Both parents alive & 96.2 & 95.0 \\
\hline \multicolumn{3}{|l|}{ Co-residence with parents (\%) } \\
\hline Currently staying with a parent & 95.6 & 93.9 \\
\hline \multicolumn{3}{|l|}{ Parents' educational attainment level } \\
\hline Median years of schooling of father & 7.0 & 7.0 \\
\hline Median years of schooling of mother & NC & 3.0 \\
\hline \multicolumn{3}{|l|}{ Sibship size } \\
\hline Number of brothers (mean) & 1.4 & 1.4 \\
\hline Number of sisters (mean) & 1.5 & 1.4 \\
\hline Number of respondents & 999 & 559 \\
\hline
\end{tabular}

Note: ${ }^{*}$ and $* * *$ indicate that differences in the means/distribution between Class 8 and Class 9 girls are significant at $p<.05$ and $p<.001$, respectively. ${ }^{1}$ Includes those who do not belong to scheduled castes, scheduled tribes or other backward castes. NC=Not calculated, because the mothers of more than half of the girls had never attended school. 
Table 1.3: Selected socio-demographic characteristics of girls who participated in the survey

\begin{tabular}{|c|c|c|}
\hline Characteristics & Class 8 girls & Class 9 girls \\
\hline \multicolumn{3}{|l|}{ Age (years) } \\
\hline Mean & $12.5 * * *$ & 13.4 \\
\hline \multicolumn{3}{|l|}{ Engagement in work in the week prior to the interview (\%) } \\
\hline Engaged in paid or unpaid work & 31.6 & 29.4 \\
\hline Paid work & 6.4 & 7.7 \\
\hline Unpaid work & 27.4 & 24.6 \\
\hline Engaged in work away from home & 29.7 & 27.3 \\
\hline Engaged in work throughout the week prior to the interview & 3.9 & 2.2 \\
\hline \multicolumn{3}{|l|}{ Engagement in work during the last school vacation (\%) } \\
\hline Engaged in paid or unpaid work & 47.8 & 48.1 \\
\hline Paid work & $20.7 *$ & 25.6 \\
\hline Unpaid work & 38.4 & 35.9 \\
\hline Engaged in work away from home & 45.7 & 46.4 \\
\hline Engaged in work throughout the last vacation & 8.2 & 7.3 \\
\hline \multicolumn{3}{|c|}{ Exposure to mass media in the month preceding the interview (\%) } \\
\hline Watched television & 95.4 & 93.3 \\
\hline Read newspapers/ magazines/ non textbooks & 81.8 & 79.9 \\
\hline Listened to radio & 7.1 & 7.5 \\
\hline Accessed internet & 1.4 & 1.9 \\
\hline Number of respondents & 999 & 559 \\
\hline
\end{tabular}

Note: ${ }^{*}$ and ${ }^{* *}$ indicate that differences in the means/distribution between Class 8 and Class 9 girls are significant at $p<.05$ and $p<.001$, respectively; ${ }^{1}$ Includes those who do not belong to scheduled castes, scheduled tribes or other backward castes.

\section{Structure of the report}

The report is divided into six chapters, including this introductory chapter. Chapter 2 describes the school experiences of the surveyed adolescent girls, including their attendance in class and academic performance. Findings concerning the girls' future aspirations, agency, gender role attitudes and time use patterns are presented in Chapter 3. Chapter 4 presents findings on the extent to which the school environment has been supportive of their schooling while Chapter 5 describes findings, as reported by the surveyed girls, on parental aspirations for the respondent's education and career, parental awareness of the girl's entitlements from school, parental discussion with the girl about her schooling, the support provided by parents in her studies, and parental interactions with her school authorities. It also describes findings related to community engagement in support of girls' education. Chapter 6 summarises the key findings of the study. 


\section{Chapter 2 \\ School experiences of girls}

This chapter describes the school experiences of the adolescent girls who participated in the survey. Specifically, it presents findings on the girls' attendance in class and the reasons for their absenteeism, if any. The chapter also presents their academic performance as measured by the scores obtained by them in competency tests, in the English and Gujarati languages and in Mathematics, administered by the study team.

\section{School attendance}

Attendance at school was measured in two ways. First, the girls who took the survey were probed about whether they had attended school on each of the six days in the week preceding the day of the interview; we note that the days in that week on which the girls reported that their school was closed because of public holidays (including Sundays) were excluded from the analysis. Second, we asked the girls whether they had missed attending school continuously for one week or more in the current academic year.

Table 2.1 presents the school attendance of the surveyed girls for the current academic year. Findings show that while the majority of girls-72 percent of Class 8 girls and 74 percent of Class 9 girls-had attended school regularly, that is, had attended on all days that the school was in session in the week prior to the interview, far too many-more than one-quarter-had missed one or more days of school that week. Both Class 8 and Class 9 girls reported that their school had been open, on average, five days in the week preceding the interview and that they had attended school, on average, on four days. Most girls who had attended school in the pre-interview week had attended all the periods on those days (96-97\%). Findings, moreover, show that 12 percent each of Class 8 and Class 9 girls had missed their class continuously for one week or more in the current academic year.

Table 2.1: Girls' school attendance during the current academic year

\begin{tabular}{|c|c|c|}
\hline School attendance of girls & Class 8 girls & Class 9 girls \\
\hline Attended school on all days that the school was in session in the week prior to the interview (\%) & 71.9 & 74.3 \\
\hline Mean number of school working days attended in the week prior to the interview & $4.2^{*}$ & 4.4 \\
\hline Mean number of school working days in the week prior to the interview & $4.7 *$ & 4.9 \\
\hline Attended all the periods on the days she attended school in the week prior to the interview (\%) & 96.5 & 95.6 \\
\hline Missed class continuously for one week or more during the current academic year (\%) & 12.2 & 12.2 \\
\hline Number of respondents & 999 & 559 \\
\hline
\end{tabular}

Note: ${ }^{*}$ indicates that the difference in the means/distribution between Class 8 and Class 9 girls is significant at $p<.05$.

\section{Reasons for absenteeism}

Table 2.2 lists the reasons cited by the surveyed girls for remaining absent from school both on any working day in the week prior to the interview (Panel A) and continuously for one week or more during the current academic year (Panel B). As indicated in Panel A, girls who missed school on any of the days that the school was in session in the pre-interview week mainly offered household-related reasons such as domestic chores, engagement in paid or unpaid work and family functions; 64 percent of Class 8 girls and 61 percent of Class 9 girls so reported. The second most frequently mentioned reason for missing school was related to such individual causes as the girl's illness and lack of interest, mentioned by 36 percent and 34 percent of Class 8 and Class 9 girls, respectively. Just one percent of Class 8 girls and none of the Class 9 cited menstruation as a reason for school absences. This may be partly because large proportions of the surveyed girls-75 percent of Class 8 girls and 46 percent of Class 9 girls-had not started menstruating at the time of the survey and partly because they may have failed to spontaneously recall menstruation as a reason for their absence; we note that in response to a direct question on school attendance during their last menstrual period, 27 percent of Class 8 girls and 16 percent of Class 9 girls who had attained menarche reported that they did not attend their class during those days (not shown in table). Only a minority of 
Class 8 girls attributed absence from school to reasons related to transportation to and from school (4\%); however, one-tenth of Class 9 girls so reported (11\%).

The reasons for missing school continuously for one week or more during the current academic year were similar to those reported for missing school at least one day in the week before the interview (Table 2.2, Panel B). Among Class 8 girls, the most frequently cited reasons were household-related (65\%), followed by individual reasons (41\%). These reasons were prominent among Class 9 girls as well (44\% and 39\%, respectively), among whom 12 percent also listed transportation-related reasons, perhaps because of the location of secondary schools outside the village of residence for most Class 9 girls. One percent of Class 8 girls and six percent of Class 9 girls cited such school-related reasons as teacher absenteeism and absence of female teachers in the school for missing school continuously for one week or more during the current academic year.

Table 2.2: Percentage of girls who missed school by reasons for absence

\begin{tabular}{|c|c|c|}
\hline Reason for absence & Class 8 girls & Class 9 girls \\
\hline \multicolumn{3}{|c|}{$\begin{array}{l}\text { A. Reasons for missing school on any of the days when the school was in session } \\
\text { during the week prior to the interview }{ }^{1}\end{array}$} \\
\hline Girl's illness & 26.5 & 21.7 \\
\hline Menstruation & 0.7 & 0.0 \\
\hline Lack of interest & 9.8 & 12.6 \\
\hline Individual-related reasons & 35.8 & 34.3 \\
\hline Domestic chores & 28.3 & 27.9 \\
\hline Responsibilities at work or of family business/farm & 13.7 & 6.7 \\
\hline Family functions & 28.8 & 28.4 \\
\hline Household-related reasons & 64.1 & 60.7 \\
\hline Transportation-related reasons & $4.4 * *$ & 11.2 \\
\hline \multicolumn{2}{|c|}{ Number of respondents who were absent at least one day in the week prior to } & 119 \\
\hline \multicolumn{3}{|c|}{$\begin{array}{l}\text { B. Reasons for missing school continuously for one week or more during the } \\
\text { current academic year }{ }^{1}\end{array}$} \\
\hline Girl's illness & 28.9 & 28.2 \\
\hline Menstruation & 1.3 & 0.0 \\
\hline Lack of interest & 14.5 & 12.9 \\
\hline Individual-related reasons & 41.0 & 38.8 \\
\hline Domestic chores & $46.2 * *$ & 26.7 \\
\hline Responsibilities at work or of family business/farm & 16.4 & 16.2 \\
\hline Family functions & 16.2 & 12.8 \\
\hline Parental objection & 0.6 & 0.0 \\
\hline Household-related reasons & $65.0 * *$ & 44.2 \\
\hline Non-payment of school fees & 0.0 & 3.5 \\
\hline Teacher absenteeism & 0.7 & 0.0 \\
\hline Absence of female teachers in the school & 0.0 & 2.3 \\
\hline School-related reasons & $0.7 *$ & 5.8 \\
\hline Transportation-related reasons & $2.7 * *$ & 12.3 \\
\hline Festival in the community & 5.2 & 8.9 \\
\hline \multicolumn{3}{|c|}{ Number of respondents who missed school continuously for one week or more } \\
\hline in the current academic year & 116 & 57 \\
\hline
\end{tabular}

Note: ${ }^{*}$ and ${ }^{*}$ indicate that differences in the means/distribution between Class 8 and Class 9 girls are significant at $p<.05$ and $p<.01$, respectively; ${ }^{1}$ Percentages exceed 100 because of multiple responses. 


\section{Academic performance}

One of the objectives of the intervention is to promote learning outcomes among Class 8 and Class 9 girls. Therefore, we administered competency tests to measure the academic performance of the girls who took the survey. We included three measures of academic performance-English language competency, Gujarati language competency and Mathematics competency. In order to assess language competency, Class 8 girls were given one paragraph each in the English and Gujarati languages, drawn from the Class 7 curriculum approved by the state education department, and asked to answer five questions relating to each paragraph. Class 9 girls were given one additional paragraph each in both these languages, drawn from the Class 8 curriculum approved by the state education department, and asked to answer five questions relating to each paragraph. The responses of the girls were assessed in terms of comprehension and sentence construction. They were given a score of 0 for no comprehension, 1 for partial comprehension and 2 for full comprehension; likewise, they were given a score of 0 for incorrect sentence construction, 1 for partially correct sentence construction and 2 for fully correct sentence construction. Two summary indices each for the English and Gujarati languages were constructed by adding the scores for comprehension and sentence construction, respectively. The value of the indices ranged from 0 to 10 for Class 8 girls and 0 to 20 for Class 9 girls. In order to test Mathematics competency, Class 8 girls were asked to solve 14 problems drawn from the Class 7 curriculum, and Class 9 girls were asked to solve five additional problems drawn from the Class 8 curriculum. These questions ranged from simple addition and subtraction to those related to polynomials. The composite indicator of Mathematics competency comprised the number of problems correctly solved, and ranged from 0 to 14 for Class 8 girls and 0 to 19 for Class 9 girls. Given that the maximum scores that Class 8 and Class 9 girls could attain differed, the scores were standardised by converting them into percentage marks.

The mean scores obtained by the surveyed girls, expressed in percentage marks, are presented in Table 2.3. Findings underscore the extremely poor academic performance of the girls. Class 8 girls scored, on average, 26 percentage marks in solving Class 7 Mathematics problems. The performance of Class 9 girls was no better; they scored, on average, 21 percentage marks in solving Class 7 and Class 8 Mathematics problems.

In English comprehension and sentence construction too, both Class 8 and Class 9 girls performed very poorly. For example, on average, Class 8 girls scored 12 and nine percentage marks for comprehension and sentence construction, respectively, and Class 9 girls scored 11 and nine percentage marks, respectively. Finally, although

Table 2.3: Girls' academic performance in selected subjects

\begin{tabular}{lrr}
\hline & \multicolumn{2}{c}{ Average marks scored } \\
Tests administered & Class 8 girls & Class 9 girls \\
\cline { 2 - 3 } Mathematics competency test (\%) & $25.5 * * *$ & $(14.6)$ \\
& $(18.1)$ & 11.0 \\
English language competency test (\%) & 12.3 & $(11.7)$ \\
Comprehension & $(16.4)$ & 8.5 \\
& 8.9 & $(9.4)$ \\
Sentence construction & $(11.7)$ & 38.3 \\
Gujarati language competency test (\%) & 38.7 & $(22.6)$ \\
Comprehension & $(24.6)$ & 36.2 \\
Sentence construction & 36.1 & $(21.9)$ \\
\hline
\end{tabular}

Note: $* * *$ indicates that the difference in the means between Class 8 and Class 9 girls is significant at $p<.001$. Figures in parentheses indicate the standard deviation. 
the girls performed better in Gujarati than in English or Mathematics, their performance in Gujarati was also far from satisfactory: on average, Class 8 girls scored 39 and 36 percentage marks for comprehension and sentence construction, respectively, and Class 9 girls scored 38 and 36 percentage marks, respectively.

Measures of academic performance of the girls who took the survey by school attendance, presented in Table 2.4, show that girls who regularly attended school scored higher than others. Even so, the average marks obtained by the

Table 2.4: Girls'academic performance by school attendance

\begin{tabular}{|c|c|c|}
\hline \multirow[b]{2}{*}{ School attendance } & \multicolumn{2}{|c|}{ Average marks scored } \\
\hline & Class 8 girls & Class 9 girls \\
\hline \multicolumn{3}{|c|}{ Mathematics competency test (\%) } \\
\hline \multicolumn{3}{|c|}{ Attended school on all days that the school was in session in the week prior to the interview } \\
\hline No & $19.2 * * *$ & $16.7 * * *$ \\
\hline Yes & 27.9 & 23.0 \\
\hline \multicolumn{3}{|c|}{ Missed class continuously for one week or more during the current academic year } \\
\hline No & $26.4 * * *$ & $22.5 * * *$ \\
\hline Yes & 19.0 & 13.3 \\
\hline \multicolumn{3}{|c|}{ English language competency test: Comprehension (\%) } \\
\hline \multicolumn{3}{|c|}{ Attended school on all days that the school was in session in the week prior to the interview } \\
\hline No & $7.1 * * *$ & $7.9 * * *$ \\
\hline Yes & 14.3 & 12.1 \\
\hline \multicolumn{3}{|c|}{ Missed class continuously for one week or more during the current academic year } \\
\hline No & $13.0 * * *$ & $11.9 * * *$ \\
\hline Yes & 7.2 & 4.7 \\
\hline \multicolumn{3}{|c|}{ English language competency test: Sentence construction (\%) } \\
\hline \multicolumn{3}{|c|}{ Attended school on all days that the school was in session in the week prior to the interview } \\
\hline No & $5.3 * * *$ & $5.7 * * *$ \\
\hline Yes & 10.3 & 9.4 \\
\hline \multicolumn{3}{|c|}{ Missed class continuously for one week or more during the current academic year } \\
\hline No & $9.4 * * *$ & $9.1 * * *$ \\
\hline Yes & 5.7 & 3.6 \\
\hline \multicolumn{3}{|c|}{ Gujarati language competency test: Comprehension (\%) } \\
\hline \multicolumn{3}{|c|}{ Attended school on all days that the school was in session in the week prior to the interview } \\
\hline No & $31.9 * * *$ & $30.7 * * *$ \\
\hline Yes & 41.4 & 39.0 \\
\hline \multicolumn{3}{|c|}{ Missed class continuously for one week or more during the current academic year } \\
\hline No & $39.5 * *$ & $40.1 * * *$ \\
\hline Yes & 33.2 & 25.3 \\
\hline \multicolumn{3}{|c|}{ Gujarati language competency test: Sentence construction (\%) } \\
\hline \multicolumn{3}{|c|}{ Attended school on all days that the school was in session in the week prior to the interview } \\
\hline No & $30.2 * * *$ & $28.5 * * *$ \\
\hline Yes & 38.5 & 39.0 \\
\hline \multicolumn{3}{|c|}{ Missed class continuously for one week or more during the current academic year } \\
\hline No & $36.9 *$ & $37.9 * * *$ \\
\hline Yes & 30.9 & 24.5 \\
\hline Number of respondents & 999 & 559 \\
\hline
\end{tabular}

Note: ${ }^{* *}$ and $* * *$ indicate that differences in the means/distribution between those who attended class regularly and those who did not, and between those who missed class continuously for one week or more and those who did not, are significant at $p<.05$, $p<.001$ and $p<.0001$, respectively. 
regular attendees were far from satisfactory. For example, while Class 8 girls who attended school on all working days in the week prior to the interview scored, on average, 28 percentage marks in Mathematics, those who missed school at least for a day in the preceding week scored only 19 percentage marks. Likewise, while Class 9 girls who did not miss school continuously for one week or more during the current academic year scored, on average, 23 percentage marks in Mathematics, their counterparts who missed school so scored only 13 percentage marks. Similar differences were evident in the marks obtained for comprehension and sentence construction in the English and Gujarati language competency tests, in respect of school attendance of girls. 


\section{Chapter 3}

\section{Girls' future aspirations, agency, gender role attitudes and time use}

The study assessed the future aspirations, agency, gender role attitudes and time use of the girls who took the survey to better understand their ability to pursue their studies. The findings of this analysis are presented in this chapter.

\section{Future aspirations}

The girls who participated in the survey were probed about their future aspirations with regard to their education and career. Specifically, they were probed about the level of education to which they aspire, and the extent to which they valued the successful completion of secondary education, as well as working for pay and working outside the home after completing their studies. The findings, presented in Table 3.1, suggest that the vast majority of girls aspired to complete at least a secondary education. Table 3.1 also shows that the educational aspirations of Class 8 and Class 9 girls differed somewhat, with Class 9 girls expressing greater educational aspirations. For example, just nine percent of Class 8 girls and two percent of Class 9 girls reported that they would like to complete nine or fewer years of schooling. In contrast, 61 percent of Class 8 girls and 58 percent of Class 9 girls expressed a desire to complete Class 10 or Classes 11-12, and 27 and 35 percent, respectively, said that they wished to complete graduation and above or some professional courses. These findings reinforce the importance of the transition from Class 8 to Class 9.

When questioned about the value they attached to completing a secondary education, most girls responded that they valued it very much, with more Class 9 than Class 8 girls reporting so (87\% versus $79 \%)$. Relatively fewer

Table 3.1: Percent distribution of girls by their aspirations about their education and career

\begin{tabular}{|c|c|c|}
\hline Educational and career aspirations & Class 8 girls & Class 9 girls \\
\hline \multicolumn{3}{|c|}{ Class up to which the girl would like to study } \\
\hline Less than Class 10 & $9.4 * * *$ & 1.8 \\
\hline Class 10 & 28.8 & 20.2 \\
\hline Classes 11-12 & 32.6 & 38.0 \\
\hline Graduation and above & 23.2 & 30.3 \\
\hline Professional courses & 3.6 & 5.0 \\
\hline Other responses & 2.5 & 4.7 \\
\hline \multicolumn{3}{|c|}{ Extent to which the girl valued completing Class 10} \\
\hline Not at all & $6.5 * * *$ & 1.7 \\
\hline Somewhat & 14.5 & 11.7 \\
\hline Very & 79.0 & 86.6 \\
\hline \multicolumn{3}{|c|}{ Extent to which the girl valued working for pay } \\
\hline Not at all & $5.1 * * *$ & 2.1 \\
\hline Somewhat & 26.7 & 25.0 \\
\hline Very & 68.2 & 72.9 \\
\hline \multicolumn{3}{|c|}{ Extent to which the girl valued working outside the home } \\
\hline Not at all & $10.0 *$ & 8.5 \\
\hline Somewhat & 46.7 & 41.8 \\
\hline Very & 43.3 & 49.8 \\
\hline Number of respondents & 999 & 559 \\
\hline
\end{tabular}

Note: ${ }^{*}$ and ${ }^{* *}$ indicate that differences in the means/distribution between Class 8 and Class 9 girls are significant at $p<.05$ and $p<.001$, respectively. 
girls highly valued working for pay after completing their studies-68 percent of Class 8 girls and 73 percent of Class 9 girls, and even fewer-43 and 50 percent of Class 8 and Class 9 girls, respectively, highly valued working outside their home after completing their studies. In addition, considerable proportions of Class 8 and Class 9 girls considered it "somewhat important" to complete a secondary education ( $15 \%$ and $12 \%$, respectively), work for pay ( $27 \%$ and $25 \%$, respectively) and work outside the home ( $47 \%$ and $42 \%$ ) after completing their studies.

\section{Girls' perceptions about their ability to perform well in school and realise their educational aspirations}

The study included a number of questions about the ability of the girls who took the survey to perform well in school and realise their educational aspirations gauged in terms of: (1) their perceived ability to perform well in school; and (2) the years of schooling that they think they would actually complete under their current circumstances.

Girls' perceptions about their ability to perform well in school were assessed from their responses to three questions. Specifically, they were asked whether they agreed or disagreed with three statements: "I will not be able to attend school regularly"; "The school lessons are difficult for me to learn"; and "I will not be able to get good marks in my examinations."

Table 3.2 presents the percentage of surveyed girls who displayed the ability to perform well at school. Most girls perceived that they would be able to attend school regularly and perform well in class. Moreover, Class 9 girls displayed higher perceived ability to perform well than Class 8 girls. For example, 93 percent of Class 9 girls compared to 84 percent of Class 8 girls disagreed with the statement that they would not be able to attend school regularly. Likewise, of Class 8 and Class 9 girls, 79 percent and 90 percent, respectively, disagreed with the statement that the school lessons were difficult for them to learn, and 72 percent and 82 percent, respectively, disagreed with the statement that they would not be able to get good marks in their examinations. It is notable that sizeable proportions of girls-66 percent of Class 8 girls and 77 percent of Class 9 girls-were fully confident of their ability to attend school regularly and perform well, as measured by their disagreement with all three statements.

Table 3.2: Percentage of girls displaying the ability to perform well at school

\begin{tabular}{lcc}
\hline${\text { Girls disagreeing with the following statements }{ }^{\mathbf{1}}}$ & Class $\mathbf{8}$ girls & Class $\mathbf{9}$ girls \\
\hline I will not be able to attend school regularly & $83.9 * * *$ & 93.0 \\
The school lessons are difficult for me to learn & $79.1 * * *$ & 89.6 \\
I will not be able to get good marks in my exams & $71.6 * * *$ & 81.7 \\
Girls who displayed the ability to perform well at school, that is, disagreed with & $65.7 * * *$ & 77.3 \\
all three statements & $\mathbf{9 9 9}$ & $\mathbf{5 5 9}$ \\
Number of respondents & & \\
\hline
\end{tabular}

Note: $* * *$ Indicates that the difference in the means/distribution between Class 8 and Class 9 girls is significant at $p<.001 .{ }^{1}$ The remaining percentages of girls either agreed with the statement or were uncertain.

Table 3.3 presents the percentage of surveyed girls by the educational level that they expected to achieve under their current circumstances and the reasons offered by those who felt that they would not actually complete the level of education that they aspired to achieve. For a notable proportion of girls, the number of years of schooling that they thought they would be able to complete fell short of what they had aspired to achieve, suggesting their perceived inability to realise their educational aspirations. For example, although 88 percent of Class 8 girls aspired to complete at least a secondary education (see Table 3.1), only 77 percent felt that they could actually complete it under their current circumstances (Table 3.3, Panel A). Likewise, while 27 percent and 35 percent of Class 8 and Class 9 girls, respectively, aspired to complete graduation and above or a professional course (see Table 3.1), only 17 percent and 24 percent, respectively, felt that they would be able to do so in their current situation (Table 3.3, Panel A). Indeed, 29 percent each of Class 8 and Class 9 girls believed that they might not be able to realise their educational aspirations in light of their current circumstances. 
Table 3.3: Percent distribution of girls by educational level they expected to attain under their current circumstances and percentage perceiving inability to attain aspired level by reasons

\begin{tabular}{|c|c|c|}
\hline $\begin{array}{l}\text { Expected educational level and reasons for perceived inability to achieve } \\
\text { aspired level }\end{array}$ & Class 8 girls & Class 9 girls \\
\hline \multicolumn{3}{|l|}{ A. Class up to which the girl expected to study under the current circumstances } \\
\hline Less than Class 10 & 19.1 & 4.8 \\
\hline Class 10 & 34.3 & 38.4 \\
\hline Classes 11-12 & 25.1 & 29.5 \\
\hline Graduation and above & 14.5 & 19.6 \\
\hline Professional courses & 2.7 & 4.1 \\
\hline Other responses & 4.3 & 3.6 \\
\hline $\begin{array}{l}\text { Girls who perceived that the number of years of schooling they were likely to } \\
\text { short of their aspirations }{ }^{1}\end{array}$ & 29.4 & 29.4 \\
\hline Number of respondents & 999 & 559 \\
\hline \multicolumn{3}{|c|}{$\begin{array}{l}\text { B. Reasons mentioned by girls who perceived that the number of years of schooling } \\
\text { they were likely to complete fell short of their aspirations }{ }^{2}\end{array}$} \\
\hline Health problems & 0.8 & 0.0 \\
\hline Poor academic competency & 0.7 & 0.0 \\
\hline Individual reasons & 1.5 & 0.0 \\
\hline Inability to afford the cost of studies & $32.4 *$ & 43.4 \\
\hline Parental disapproval & $48.8 * *$ & 33.2 \\
\hline Plans for marriage & $0.9 *$ & 3.7 \\
\hline Occupied with household chores & 17.2 & 14.9 \\
\hline Involved in wage work & 6.7 & 2.3 \\
\hline Household-related reasons & 75.5 & 75.2 \\
\hline Lack of a secondary school in the village & $47.5 *$ & 35.2 \\
\hline Irrelevance of current curriculum & 1.3 & 1.8 \\
\hline Poor quality of teaching & 3.4 & 1.4 \\
\hline School-related reasons & $51.3 * *$ & 38.5 \\
\hline Lack of transportation & 9.8 & 12.3 \\
\hline Lack of escort to go to school & 1.4 & 2.0 \\
\hline Concerns about safety & 0.0 & 0.6 \\
\hline Transportation-related reasons & 10.9 & 14.9 \\
\hline Unfavourable community norms & 2.2 & 0.0 \\
\hline \multicolumn{3}{|c|}{ Number of respondents who perceived that the level of education they would actually } \\
\hline be able to complete fell short of their aspirations & 285 & 157 \\
\hline
\end{tabular}

Note: ${ }^{*}$ and $* *$ indicate that differences in the means/distribution between Class 8 and Class 9 girls are significant at $p<.05$ and $p<.01$, respectively. ${ }^{1}$ About $2 \%$ of girls are not shown in the table because it was difficult to delineate whether the years of schooling that they thought they would be able to complete fell short of their aspired level. ${ }^{2}$ Percentages exceed 100 because of multiple responses.

Table 3.3, Panel B, shows that the surveyed girls who perceived that they would not be able to realise their educational aspirations cited a number of reasons. Most prominent among the reasons were those related to household matters, with three-quarters of girls attributing their perceived inability to study as much as they wished to household-related reasons. Notably, among girls in Class 8, 49 percent cited parental disapproval, 32 percent 
stated their inability to afford the cost of studies and 17 percent mentioned lack of time due to household chores; the corresponding percentages among Class 9 girls were 33, 43 and 15, respectively. Interestingly, just one and four percent of girls in Class 8 and Class 9 , respectively, mentioned plans for marriage as a reason for believing that they would not be able to realise their educational aspirations. School-related reasons were also frequently mentioned; 51 percent of Class 8 girls and 39 percent of Class 9 girls who perceived that they would be unable to attain their educational ambitions mentioned school-related reasons, particularly, the absence of a secondary school in their village in which they could pursue further studies. Indeed, one-third of Class 8 girls and one-fifth of Class 9 girls who so perceived cited both household and school-related reasons (not shown in table). Reasons related to lack of transportation were mentioned by 11 percent of Class 8 girls and 15 percent of Class 9 girls who felt that they would not be able to achieve their scholastic ambitions either for lack of transportation to commute to school or for lack of an escort. Finally and notably, just two percent each of Class 8 girls and none of the Class 9 girls mentioned such individual reasons as lack of interest, health problems, poor academic competency, and unfavourable community norms.

\section{Agency}

We used three indictors to measure the agency of the girls who took the survey: (1) decision-making say with regard to the level of schooling that the girl should have, (2) ability to negotiate with parents on schooling and work, and (3) communication skills. Specifically, the girls were asked who would decide how much schooling they should have, and all those who responded that they would decide on their own or jointly with others were considered to have a decision-making say. Girls' perceived negotiation skills were measured using two questions that assessed whether, if their parents' preferences about their education and work differed from their own, they would be able to convince their parents either on their own or with the help of others, or they would go against their parents' preference. Girls' communication skills were measured based on their responses to three questions that assessed whether they found it difficult to express their opinion to elders in their family, or to confront classmates who hurt their feelings, and whether they felt comfortable speaking in front of a group. Girls who replied that they never found it difficult to express their opinion to family elders or to confront classmates who hurt their feelings, or always felt comfortable speaking in front of a group were considered to have good communication skills in at least one situation.

Table 3.4 presents the surveyed girls' responses expressed as percentages of girls who displayed agency. As seen in table, the girls showed limited agency with Class 9 girls displaying greater agency than Class 8 girls. For example, just 37 percent of Class 8 girls and 46 percent of Class 9 girls reported that they would have a say in decisions related to the level of schooling that they should have. Their ability to negotiate with their parents regarding their education and career if their parents held a different opinion from theirs was also limited: just 50 percent of Class 8 girls and 55 percent of Class 9 girls said that if their parents' opinion differed from their own, they would convince their parents or go against their parents' opinion with regard to their schooling. Fewer girls-41 percent of Class 8 girls and 45 percent of Class 9 girls-replied that they would do so with regard to their career. Finally, the girls' communication skills were also restricted in that just 57-59 percent of girls displayed confidence in their ability to communicate their opinion without any discomfort in at least one out of the three scenarios included in the study.

Table 3.4: Percentage of girls displaying agency

\begin{tabular}{lcc}
\hline Demonstration of agency by girls & Class 8 girls & Class $\mathbf{9}$ girls \\
\hline Reported a say in decisions related to the level of schooling she should have & $36.7^{* * *}$ & 45.7 \\
Displayed skills to negotiate with her parents on & & \\
Her education & 50.4 & 55.0 \\
Her intention to work & 40.8 & 45.1 \\
Displayed communication skills & 57.2 & 58.5 \\
Number of respondents & $\mathbf{9 9 9}$ & $\mathbf{5 5 9}$ \\
\hline
\end{tabular}

Note: $* *$ indicates that the difference in the means/distribution between Class 8 and Class 9 girls is significant at $p<.001$. 


\section{Gender role attitudes}

Girls' gender role attitudes were measured using three indicators: (1) girls' perceptions about the optimal level of education that girls and boys should have and the reasons for differences, if any, in their perceptions; (2) an index of gender role attitudes based on responses to three questions related to the differential ability of girls and boys to perform in selected subjects, and (3) their perceptions about the importance of educating boys compared to girls. Questions included in the index of gender role attitudes assessed whether the respondent believed that both boys and girls are equally able to learn Mathematics, and the English and Gujarati languages. The respondent was given a score of 1 for each gender egalitarian statement with which she agreed and 0 otherwise; the scores were summed to create the index, the value of which ranged from 0 , indicating adherence to gender inegalitarian norms, to 3 , indicating adherence to gender egalitarian norms (Cronbach's alpha $=0.64$ for Class 8 girls and 0.71 for Class 9 girls), suggesting that the items included in the index have acceptable to good levels of internal consistency).

Table 3.5 which sums up the perceptions of the surveyed girls on the ideal educational level for girls and boys indicates that their perceptions were clearly gendered. For example, the proportion of girls who suggested Class 10 as the ideal level of education for girls was much larger than the proportion suggesting this level as ideal for boys: 21 percent and three percent, respectively, of Class 8 girls, and 15 percent and one percent, respectively, of Class 9 girls. In contrast, the proportion of girls who considered a Bachelor's degree and above or a professional course as the ideal level of education for boys was larger than the proportion of girls who considered so for girls-51 percent versus 28 percent among Class 8 girls, and 61 percent versus 41 percent among Class 9 girls.

Table 3.5: Percent distribution of girls by perceptions about the ideal level of education for girls and boys

\begin{tabular}{|c|c|c|}
\hline Perceptions about the ideal level of education & Class 8 girls & Class 9 girls \\
\hline \multicolumn{3}{|l|}{ Level of education boys should have } \\
\hline Less than Class 10 & $0.4 * * *$ & 0.1 \\
\hline Class 10 & 3.3 & 1.4 \\
\hline Classes 11-12 & 34.3 & 24.0 \\
\hline Graduation and above & 48.5 & 57.4 \\
\hline Professional courses & 2.7 & 4.0 \\
\hline Other responses & 10.8 & 13.1 \\
\hline \multicolumn{3}{|l|}{ Level of education girls should have } \\
\hline Less than Class 10 & $1.3 * * *$ & 0.0 \\
\hline Class 10 & 21.2 & 14.8 \\
\hline Classes 11-12 & 45.4 & 39.9 \\
\hline Graduation and above & 26.4 & 39.9 \\
\hline Professional courses & 1.6 & 1.0 \\
\hline Other responses & 4.1 & 4.4 \\
\hline Number of respondents & 999 & 559 \\
\hline
\end{tabular}

Note: $* * *$ indicates that the difference in the means/distribution between Class 8 and Class 9 girls is significant at $p<.001$.

As seen in Table 3.6, the reasons that the surveyed girls attributed for suggesting that boys and girls should complete at least Class 10 were also gendered. Girls were likely to cite better career prospects as the reason for attaining no less than Class 10 more often for boys than for girls. For example, 90-91 percent of girls reported that boys should complete at least Class 10 for better career prospects, while fewer so reported in the case of girls (70-72\%). In contrast, they were likely to suggest better marriage prospects and acquiring skills to deal with day-to-day matters as reasons more often for girls than for boys (20\% versus $7-9 \%$, and $57-60 \%$ versus $42-45 \%$, respectively). 
Table 3.6: Percentage of girls reporting that boys and girls should complete at least Class 10 by reasons

\begin{tabular}{lcc}
\hline Reasons & Class $\mathbf{8}$ girls & Class $\mathbf{9}$ girls \\
\hline Reasons why boys should complete at least Class $\mathbf{1 0}$ & 22.3 & 25.3 \\
To earn respect in society and for family & 44.5 & 42.0 \\
To acquire skills to deal with day-to-day matters & 90.3 & 7.4 \\
To better career prospects & $2.6 * *$ & 9.0 \\
To better marriage prospects & $\mathbf{9 6 7}$ & 5.5 \\
To be able to support his family & $17.8 *$ & $\mathbf{5 4 6}$ \\
Number of respondents reporting that boys should complete at least Class $\mathbf{1 0}$ & 59.5 & 23.2 \\
Reasons why girls should complete at least Class 10 & 69.5 & 57.2 \\
To earn respect in society and for family & 19.7 & 72.0 \\
To acquire skills to deal with day-to-day matters & 1.8 & 19.9 \\
To better career prospects & $\mathbf{9 7 8}$ & 2.2 \\
To better marriage prospects & $\mathbf{5 5 2}$ \\
To be able to support her family & & \\
Number of respondents reporting that girls should complete at least Class $\mathbf{1 0}$ & & \\
\hline
\end{tabular}

Note: ${ }^{*}$ and ${ }^{*}$ indicate that differences in the means/distribution between Class 8 and Class 9 girls are significant at $p<.05$ and $p<.01$, respectively. Percentages exceed 100 because of multiple responses.

Table 3.7 which shows the percentage of surveyed girls who displayed egalitarian attitudes indicates that girls' perceptions about the ability of girls and boys to learn different subjects like Mathematics and the English and Gujarati languages were also gendered. Girls scored 1.6-1.7 on a scale that measured their perceptions of the ability of boys and girls to perform equally well in all three subjects. Likewise, only 69 percent of Class 8 girls and 77 percent of Class 9 girls believed that educating girls is as important as educating boys.

Table 3.7: Gender egalitarian attitudes of girls

\begin{tabular}{lcc}
\hline Gender egalitarian attitudes & Class 8 girls & Class $\mathbf{9}$ girls \\
\hline Mean score, index of gender role attitudes (range 0-3) & 1.7 & 1.6 \\
Girls who think that educating girls is as important as educating boys (\%) & $69 * * *$ & 77 \\
Number of respondents & $\mathbf{9 9 9}$ & $\mathbf{5 5 9}$ \\
\hline
\end{tabular}

Note: $* * *$ indicates that the difference in the means/distribution between Class 8 and Class 9 girls is significant at $p<.001$.

\section{Time use}

Time use data were collected from all the girls who took the survey, asking them to recall their activities in halfhour increments for the 24-hour period of the last school day they attended; assuming at least four hours of sleep, they were asked to record activities for a total of 20 hours. The interviewer recorded their responses according to appropriate categories. In our analysis, we focus on three broad categories of time-time devoted to school activities, time devoted to all types of work, and time devoted to leisure. Time devoted to school activities included time spent in school, in doing homework and commuting between school and home. Work time included time spent on paid work, unpaid work and non-economic household chores. 
Table 3.8: Time use pattern of girls

\begin{tabular}{lcc}
\hline & \multicolumn{2}{c}{ Average number of hours spent by } \\
\cline { 2 - 3 } Activities on the last day of school & Class $\mathbf{8}$ girls & Class girls \\
\hline In school & $5.5^{* * *}$ & 5.1 \\
Doing homework & $1.6^{* * *}$ & 2.0 \\
In transit from home to school and back & $0.4 * * *$ & 0.8 \\
Domestic duties at home & 2.1 & 2.2 \\
Domestic duties outside home & 0.5 & 0.5 \\
Care of children, sick and elderly persons & 0.1 & 0.1 \\
Helping in family farm or business & 0.2 & 0.2 \\
Employment outside family & 0.0 & 0.0 \\
In transit (other than school or domestic duties) & 0.1 & 0.1 \\
Personal care & 1.8 & 1.8 \\
Social and recreational activities & $2.4 * *$ & 2.1 \\
Rest/sleep (includes time spent as sick) & $5.4 * * *$ & 5.1 \\
Total number of hours & 20.0 & 20.0 \\
Number of respondents & $\mathbf{9 6 3}$ & $\mathbf{5 4 4}$ \\
\hline
\end{tabular}

Note: ${ }^{*}$ and $* * *$ indicate that differences in the means/distribution between Class 8 and Class 9 girls are significant at $p<.01$ and $p<.001$, respectively.

The girls' time use patterns, presented in Table 3.8, show that, on the last school day, Class 8 and Class 9 girls spent, on average, 7.5 hours and 7.9 hours, respectively, on school-related activities. Besides, they spent, on average, almost three hours on work, most of which comprised household chores. Finally, they enjoyed, on average, two hours of leisure time. 


\section{Chapter 4}

\section{School environment of adolescent girls}

This chapter describes the conduciveness of the school environment to adolescent girls in our study for pursuing and performing well in their studies. Specifically, it presents findings about physical access to the school they are currently attending and the availability of facilities and teachers in their school. In addition, it describes findings related to the efforts made by the school to make the girls aware of and utilise their entitlements from school. Also presented are findings related to the girls' reports of their teachers' attendance in class and classroom dynamics, including the extent to which the girls were involved in non-academic activities, and their access to a trusted adult at school with whom they could discuss their personal problems. Finally, the chapter describes the extent to which the girls reported a safe environment in their school and village.

\section{Physical access to school}

Physical access to school was assessed by probing the surveyed girls about the time taken to reach school, the mode of transportation that they relied on to commute to school, difficulties experienced while travelling to school and their perceptions about safety. The findings, presented in Table 4.1, suggest that Class 8 girls took, on average, 12 minutes to reach their school and Class 9 girls, 21 minutes, reflecting easier access to primary than secondary schools. The mode of transportation to and from school differed between Class 8 and Class 9 girls. Almost all Class 8 girls walked to and from their school (97\%); although the majority of Class 9 girls also went on foot to school, fewer did so (68\%).

Table 4.1: Percentage of girls reporting physical access to school

\begin{tabular}{lcc}
\hline Indicators of physical access to school & Class $\mathbf{8}$ girls & Class $\mathbf{9}$ girls \\
\hline Time taken to reach school from home in minutes [mean] & $11.7 * * *$ & \\
Mode of transportation to and from school & $97.1 * * *$ & 68.1 \\
Walking & 0.6 & 2.2 \\
School transportation & 0.3 & 14.7 \\
Public transportation & 0.5 & 8.3 \\
Private transportation & 1.5 & 6.7 \\
Own transportation & $2.5 * * *$ & 14.4 \\
Experienced difficulty in commuting to school during the current academic year & $92.0 * * *$ & 85.0 \\
Always feel safe on the trip to school & 93.6 & 92.0 \\
Feel safe walking alone in the village & 69.3 & 72.4 \\
Feel safe alone at a bus stop & $\mathbf{9 9 9}$ & $\mathbf{5 5 9}$ \\
Number of respondents ${ }^{1}$ & & \\
\hline
\end{tabular}

Note: $* *$ indicates that the difference in the means/distribution between Class 8 and Class 9 girls is significant at $p<.001$; ${ }^{1}$ Excludes two girls about whom information was missing.

A negligible minority of Class 8 girls (3\%) and many more Class 9 girls (14\%) reported that they had experienced some difficulty in commuting to school during the current academic year. Class 9 girls who so reported cited issues primarily related to public transportation, that is, no service, lack of money to pay the bus fare and irregular bus service (77\%); some ten percent reported harassment on the way, and 13 percent reported poor road conditions and bad weather (not shown in table).

To assess the girls' perceptions of safety, they were probed about whether they always felt safe on their trip to school, walking alone in their village and on being alone at a bus stop. In general, the majority of girls said that they felt safe; 
for example, 92 percent of Class 8 girls and 85 percent of Class 9 girls reported that they always felt safe on their way to school. Findings, moreover, show that the girls' sense of safety differed by their situation; regardless of the class they attended, the girls were most likely to feel safe walking alone in their village (92-94\%) and least likely to feel safe if they were alone at a bus stop (69-72\%).

\section{Facilities and teachers available in schools}

The infrastructure of the schools currently attended by the surveyed girls was measured in terms of the availability of: (1) comfortable classrooms as assessed by the availability of desks for students, blackboards, and seating arrangements that enabled students to hear the teacher clearly, see the blackboard clearly and write comfortably; (2) a library with borrowing facilities for students; (3) laboratory facilities; (4) separate girls' toilets; (5) drinking water; and (6) playgrounds or playing fields. ${ }^{1} \mathrm{~A}$ composite indicator of school infrastructure was created, that was set to equal 1 if all six items described above were available and 0 if not.

As evident from Table 4.2, Panel A, school infrastructure was inadequate on several counts. For example, just 28 percent of Class 8 girls and 45 percent of Class 9 girls reported that their school had all the amenities measured by the study. Moreover, the accounts of Class 8 and Class 9 girls differed in terms of the availability of school infrastructure; for example, Class 9 girls were more likely than Class 8 girls to report the availability of comfortable classrooms (90\% versus $77 \%$ ), laboratory facilities (66\% versus $50 \%)$, and drinking water supply (93\% versus $85 \%)$. However, Class 8 girls were more likely than Class 9 girls to report access to a library with borrowing facilities (87\% versus $70 \%)$.

Table 4.2: Percentage of girls reporting the availability of selected items of infrastructure and number of teachers in their school

\begin{tabular}{|c|c|c|}
\hline Infrastructure and teachers available & Class 8 girls & Class 9 girls \\
\hline \multicolumn{3}{|l|}{ Infrastructure available } \\
\hline Comfortable classrooms & $77.0 * * *$ & 89.8 \\
\hline Library with borrowing facilities for students & $86.8 * * *$ & 70.2 \\
\hline Laboratory facilities & $50.4 * * *$ & 66.0 \\
\hline Drinking water supply & $85.0 * * *$ & 93.4 \\
\hline Separate girls' toilets & 86.1 & 89.5 \\
\hline Playgrounds or playing fields & 99.3 & 99.3 \\
\hline Girls reporting all amenities mentioned above & $28.3 * * *$ & 44.8 \\
\hline \multicolumn{3}{|l|}{ Availability of teachers } \\
\hline \multicolumn{3}{|l|}{ Number of teachers who taught the girl ${ }^{1}$} \\
\hline $1-2$ & $17.0 * * *$ & 9.8 \\
\hline $3-4$ & 61.3 & 52.8 \\
\hline $5+$ & 21.6 & 37.5 \\
\hline Mean number of teachers who taught the girl ${ }^{1}$ & $3.6 * * *$ & 4.5 \\
\hline Mean number of female teachers ${ }^{2}$ & 0.9 & 0.5 \\
\hline Mean number of male teachers ${ }^{2}$ & 2.6 & 3.7 \\
\hline Number of respondents & 999 & 559 \\
\hline
\end{tabular}

Note: $* *$ indicates that the difference in the means/distribution between Class 8 and Class 9 girls is significant at $p<.001$, respectively. ${ }^{1}$ Excludes three girls about whom information was missing. ${ }^{2}$ Data on sex-disaggregated data on teachers were obtained from the school principal.

${ }^{1}$ The school characteristics described in this section reflect completely different schools for Class 8 and Class 9 girls. 
Table 4.2, Panel B, indicates that on average, Class 8 girls were taught by 3.6 teachers; the corresponding figure for Class 9 girls was 4.5 teachers. Findings also show that male teachers outnumbered female teachers in both Class 8 and Class 9 (2.6 versus 0.9 who taught Class 8 , and 3.7 versus 0.5 who taught Class 9). Moreover, a sizeable proportion of girls, particularly Class 8 girls, attended schools having just 1-2 teachers-17 percent of Class 8 girls and ten percent of Class 9 girls.

\section{Awareness and utilisation of entitlements that could improve economic access to schooling}

Many schemes have been implemented in Gujarat that seek to improve economic access to schooling; for example, the provision of scholarships and stipends, free uniforms and free textbooks. We assessed the efforts made by schools to make girls aware of and utilise these entitlements by probing the girls participating in our study about their awareness and utilisation of these schemes. The findings, shown in Table 4.3, indicate that most of the girls were aware of these schemes. For example, 99 percent of Class 8 girls and 97 percent of Class 9 girls said that they were aware that students are entitled to receive free textbooks. Likewise, 99 percent each of Class 8 and Class 9 girls reported that they had heard about scholarships to which students are entitled. Fewer girls reported that they had heard about students' entitlement to free uniforms -74 percent of Class 8 girls and 58 percent of Class 9 girls.

Although almost all the surveyed girls had heard about the scholarships that students are entitled to, in-depth awareness of the schemes was limited. For example, less than one percent of girls in both Class 8 and Class 9 mentioned correctly the name of at least one scholarship. However, only 19 percent of Class 8 girls and 20 percent of Class 9 girls were able to correctly identify the eligibility criteria and the amount of money awarded for at least one scholarship.

Table 4.3: Percentage of girls who were aware of entitlements from school

\begin{tabular}{|c|c|c|}
\hline Awareness of entitlements & Class 8 girls & Class 9 girls \\
\hline Free textbooks & $99.3 * * *$ & 96.8 \\
\hline Free uniform & $74.3 * * *$ & 57.6 \\
\hline Scholarships & 98.9 & 98.6 \\
\hline \multicolumn{3}{|l|}{ In-depth awareness of scholarships } \\
\hline Girls who could correctly name at least one scholarship & 0.2 & 0.6 \\
\hline $\begin{array}{l}\text { Girls who could correctly identify the eligibility criteria and the amount of money for } \\
\text { at least one scholarship }\end{array}$ & 19.0 & 20.3 \\
\hline Number of respondents & 999 & 559 \\
\hline
\end{tabular}

Note: $* * *$ indicates that the difference in the means/distribution between Class 8 and Class 9 girls is significant at $p<.001$.

The levels of utilisation of the entitlements were lower than the levels of the girls' awareness of these entitlements, particularly in the case of uniforms and scholarships (Table 4.4). Findings, moreover, show that Class 8 girls were more likely than Class 9 girls to have availed of these entitlements. For example, 98 percent of Class 8 girls compared to 75 percent of Class 9 girls had received free textbooks during the current academic year, and just 6-7 percent of Class 8 girls had obtained free uniforms and scholarships compared to one percent of Class 9 girls.

Table 4.4: Percentage of girls who had received their entitlements during the current academic year

\begin{tabular}{lcc}
\hline Type of entitlement received & Class $\mathbf{8}$ girls & Class $\mathbf{9}$ girls \\
\hline Free textbooks & $97.6 * * *$ & 74.9 \\
All & $91.9 * * *$ & 42.4 \\
Some & 5.7 & 32.3 \\
Free uniform & $6.3 * * *$ & 1.4 \\
Scholarships & $6.5 * * *$ & 0.8 \\
Number of respondents & $\mathbf{9 9 9}$ & $\mathbf{5 5 9}$ \\
\hline
\end{tabular}

Note: $* * *$ indicates that the difference in the means/distribution between Class 8 and Class 9 girls is significant at $p<.001$. 
Given that several scholarship schemes target socially and economically disadvantaged population groups, we conducted a separate analysis to study the extent to which girls in our study who belonged to disadvantaged households had received scholarships during the current academic year. The findings, presented in Table 4.5, show that although girls belonging to scheduled castes/tribes were more likely than others to have received scholarships, only a few girls had so benefitted. For example, just 14 percent of Class 8 girls from scheduled castes/tribes had received a scholarship compared to five percent of girls belonging to other castes; the corresponding percentages among Class 9 girls were 1.8 and 0.5 .

The utilisation of scholarship schemes did not differ by household economic status, as measured by wealth quintiles, among Class 9 girls (Table 4.5). However among Class 8 girls, it is notable that the poorest groups were somewhat less likely than those belonging to upper wealth quintiles to have benefitted from scholarships.

Table 4.5: Percentage of girls who had received scholarships during the current academic year by caste and household economic status

\begin{tabular}{lcc}
\hline Caste and economic status & Class $\mathbf{8}$ girls & Class $\mathbf{9}$ girls \\
\hline Caste & & \\
Scheduled castes/tribes & $13.5^{* * *}$ & 1.8 \\
Other & $5.0^{* * *}$ & 0.5 \\
Household economic status & & \\
1st and 2nd quintiles & $5.5^{* *}$ & 0.6 \\
3rd quintile & $6.0^{*}$ & 0.8 \\
4th and 5th quintiles & $7.7^{*}$ & 0.9 \\
Number of respondents & $\mathbf{9 9 9}$ & $\mathbf{5 5 9}$ \\
\hline
\end{tabular}

Note: ${ }^{* *}$ and $d^{* * *}$ indicate that differences in the means/distribution between Class 8 and Class 9 girls are significant at $p<.05$, $p<.01$ and $p<.001$, respectively.

\section{Teacher attendance in school}

The study included a series of questions to assess teacher attendance in the schools which the surveyed girls currently attended as well as to assess classroom dynamics. To measure teacher attendance, we probed the surveyed girls about their teachers' presence on each of the six days the school was in session in the week preceding the day of the interview. Table 4.6 presents these findings.

Notable proportions of girls reported that at least one of their teachers was absent at least one day in the week prior to the interview ( $37 \%$ of Class 8 girls and $45 \%$ of Class 9 girls). The subjects taught by teachers who were absent comprised languages, science, social studies, mathematics and extra-curricular activities (not shown in table).

Table 4.6: Percentage of girls reporting their teachers' attendance in school

\begin{tabular}{lcc}
\hline Teacher absenteeism & Class $\mathbf{8}$ girls & Class $\mathbf{9}$ girls \\
\hline Girls who reported that one of their teachers was absent at least one day in & $37.3 * *$ & 45.0 \\
the week prior to the interview ${ }^{1}$ & & \\
Management of teacher absenteeism $^{2}$ & & 91.2 \\
Another teacher took the class or gave the students an assignment & 34.2 & 90.0 \\
A student was instructed to supervise & 18.8 & 35.8 \\
Students were left unsupervised in the classroom & $0.3 * * *$ & 20.4 \\
Students were sent home & $\mathbf{9 9 9}$ & 2.0 \\
Number of respondents & $\mathbf{5 5 9}$ \\
\hline
\end{tabular}

Note: **and***indicate that differences in the means/distribution between Class 8 and Class 9 girls are significant at $p<.01$ and $p<.001$, respectively. ${ }^{1}$ Excludes three girls about whom information was missing. ${ }^{2} 2-3 \%$ of girls who reported that their teachers had never been absent have not been shown in the table. Percentages exceed 100 because of multiple responses. 
Table 4.6 also shows that the vast majority of girls reported that another teacher had either taken the absent teacher's class or had given the students an assignment to complete during that class (reported by $91 \%$ of Class 8 girls and $90 \%$ of Class 9 girls). One-third of the girls reported that a student was instructed to supervise the class and one-fifth reported that they were left unsupervised.

\section{Classroom dynamics}

Several dimensions of classroom dynamics were assessed in the study; specifically, the extent to which the girls' teachers displayed positive, respectful, non-discriminatory and gender egalitarian attitudes and practices; perpetration of corporal punishment, and verbal and sexual harassment by teachers; and engagement of girls in non-academic tasks.

Four indicators were developed from the responses of the surveyed girls reflecting the extent to which the teachers displayed positive, respectful, non-discriminatory and gender egalitarian attitudes and practices in the classroom toward students, in general, in the week prior to the interview. The first indicator assessed whether the teachers provided positive feedback to students in general, that is, whether they had praised students who had done well in class in the pre-interview week. The second indicator captured whether the teachers had treated students with respect in the week prior to the interview, that is, had never scolded students when they did not understand their lessons and never called them "stupid". The third measure assessed whether the teachers had discriminated against certain students on the basis of five selected characteristics, that is, gender, religion, caste, economic status and physical appearance, in the week prior to the interview. The fourth indicator measured whether the teachers had conveyed egalitarian gender role attitudes to the students in the week before the interview; the girls in our survey were probed about whether any teacher had ever made comments, in the week preceding the interview, that implied that boys should concentrate on their studies as they would have to take care of family responsibilities or that girls should be helping their mothers instead of wasting their time at school. Girls who reported that their teachers had never made either of these comments were considered to have teachers who displayed egalitarian gender role attitudes.

Table 4.7 presents the percentage of surveyed girls who reported that their teachers had displayed positive, respectful, non-discriminatory and gender egalitarian attitudes and practices in the week prior to the interview, as assessed by these four indicators. Findings show that most girls reported that their teachers had provided positive feedback to students, that is, praised students when they did well in class (reported by $79 \%$ of Class 8 girls and $77 \%$ of Class 9 girls), with no more than modest differences between Class 8 and Class 9 girls. At the same time, one-fifth of girls reported that their teachers had not given any such positive feedback to students during that week.

Fewer girls reported, in contrast, that in the week before the interview, their teachers had treated students with respect, that is, had not scolded them when they did not understand their lessons or called them "stupid" (51\% and $56 \%$ of Class 8 and Class 9 girls, respectively). Interpreted differently, disturbing proportions of girls (44-49\%) reported that their teacher had indeed scolded students when they had not understood their lessons or had called them "stupid".

Table 4.7: Percentage of girls reporting that their teachers displayed positive, respectful, non-discriminatory and gender egalitarian attitudes and practices, in the week preceding the interview

\begin{tabular}{lcc}
\hline Teachers' attitudes and practices & Class 8 girls & Class 9 girls \\
\hline Teachers provided positive feedback to students & 79.0 & 77.0 \\
Teachers treated students with respect & $50.6^{*}$ & 56.2 \\
Teachers did not discriminate against students on any grounds & $91.7 * *$ & 95.5 \\
Teachers conveyed egalitarian gender role attitudes & $72.9 * *$ & 79.9 \\
Number of respondents $^{1}$ & $\mathbf{9 9 9}$ & $\mathbf{5 5 9}$
\end{tabular}

Note: ${ }^{*} a n{ }^{\star *}$ indicate that differences in the means/distribution between Class 8 and Class 9 girls are significant at $p<.05$ and $p<.01$, respectively. ${ }^{1}$ Excludes five girls about whom information was missing. 
Table 4.7 further shows that over 90 percent of the girls who took the survey reported that their teachers had not discriminated against students on any grounds, that is, on the grounds of gender, religion, caste, economic status or physical appearance. Class 9 girls were somewhat more likely than Class 8 girls to so report (96\% versus $92 \%$ ). Fewer girls, however, reported that their teachers had conveyed egalitarian gender role attitudes. Specifically, 73 percent of Class 8 girls and 80 percent of Class 9 girls reported that their teachers had not made comments implying that boys should concentrate on their studies as they would have to take care of family responsibilities or that girls should be helping their mothers instead of wasting their time at school. At the same time, it may be noted that one-quarter of Class 8 girls and one-fifth of Class 9 girls reported that their teachers had conveyed gender inegalitarian attitudes in the classroom.

Three indicators were used to capture the surveyed girls' own experience of corporal punishment, and verbal and sexual harassment perpetrated by their teachers. The first measure captured whether the girls had experienced any corporal punishment perpetrated by any of their teachers-having been sent out of class, made to stand for prolonged periods of time in the classroom, made to stand in the courtyard or playground, or hit or beaten. Girls who reported that they had experienced any of these punishments in the week prior to the interview were considered to have experienced corporal punishment. Verbal harassment was captured by the girls' responses to three questions about whether, in the week preceding the interview, any of their teachers had teased or mocked them based on their appearance, scolded them when they did not understand their lessons, and called them "stupid". Girls who answered in the affirmative to at least one of the three questions were considered to have experienced verbal harassment perpetrated by their teachers. To assess the experience of sexual harassment, the girls were asked whether, during the pre-interview week, any of their teachers had ever looked at them in a 'bad' way, or touched them in a 'bad' way, that is, in a sexual way. Girls who reported in the affirmative to any one of the two questions were considered to have experienced sexual harassment.

Table 4.8 presents the girls' experience of corporal punishment, and verbal and sexual harassment perpetrated by their teachers. Findings show that although corporal punishment is disallowed in schools, six percent of Class 8 girls and five percent of Class 9 girls had experienced it in the week prior to the interview. Sexual harassment by teachers was reported by less than two percent of Class 8 girls and one percent of Class 9 girls. However, far more girls from both classes had experienced verbal harassment by teachers-15 percent of Class 8 girls and ten percent of Class 9 girls. Overall, almost one-fifth of Class 8 girls and one-seventh of Class 9 girls had experienced at least one form of harassment at the hands of their teachers in the week before the interview.

Table 4.8: Percentage of girls reporting experience of corporal punishment, verbal harassment or sexual harassment perpetrated by their teacher, in the week preceding the interview

\begin{tabular}{lcc}
\hline Experience of harassment by girls in the week prior to the interview & Class $\mathbf{8}$ girls & Class $\mathbf{9}$ girls \\
\hline Experienced corporal punishment & 6.3 & 4.8 \\
Experienced sexual harassment & 1.6 & 0.9 \\
Experienced verbal harassment & $14.7 * *$ & 10.5 \\
Experienced any one of the above & $19.2 * *$ & 13.8 \\
Number of respondents & $\mathbf{9 9 9}$ & $\mathbf{5 5 9}$ \\
\hline
\end{tabular}

Note: * *indicates that the difference in the means/distribution between Class 8 and Class 9 girls is significant at $p<.01$

We also probed the girls who took the survey about whether they had been engaged in non-academic tasks in school in the week prior to the interview. The findings, presented in Table 4.9, indicate that the vast majority of girls had been involved in a number of chores in their school during that week, with Class 8 girls being more likely than Class 9 girls to so report. For example, 89 percent of Class 8 girls compared to 52 percent of Class 9 girls reported having performed such chores as cleaning classrooms and school toilets, gardening, fetching water, preparing meals in the school, running errands for teachers as also assisting them at home. The chores that both Class 8 and Class 9 girls had frequently undertaken included cleaning classrooms (81\% and 33\%, respectively) and gardening (46\% and 24\%, respectively). In addition, sizeable proportions of Class 8 girls reported that they had been engaged in such chores as running errands for the teachers (38\%), fetching water (36\%), and cleaning school toilets (20\%). 
Table 4.9: Percentage of girls performing non-academic tasks in school, in the week preceding the interview

\begin{tabular}{lcc}
\hline Non-academic tasks performed & Class $\mathbf{8}$ girls & Class $\mathbf{9}$ girls \\
\hline Cleaning classrooms & $81.1 * * *$ & 32.9 \\
Gardening & $45.8 * * *$ & 23.7 \\
Running errands for the teachers & $37.7 * * *$ & 12.8 \\
Fetching water & $35.9 * * *$ & 10.2 \\
Cleaning toilets & $19.9 * * *$ & 5.3 \\
Preparing and serving food in the school & $9.3 * * *$ & 1.0 \\
Assisting teacher at her or his home & $2.0 *$ & 0.7 \\
At least one of these tasks & $89.4 * * *$ & 51.8 \\
Number of respondents & $\mathbf{9 9 8}$ & $\mathbf{5 5 5}$ \\
\hline
\end{tabular}

Note: ${ }^{*}$ and $* * *$ indicate that differences in the means/distribution between Class 8 and Class 9 girls are significant at $p<.05$ and $p<.001$, respectively.

\section{Access to a trusted adult at school for discussing personal problems}

The girls who took the survey were probed about whether there were any adults in their school whom students could approach for advice and with whom they could discuss their personal problems, and whether they had sought advice from such a person, if any. Their responses, presented in Table 4.10, indicate that one-half or more of the girls reported access to such a person in their school with whom they could share their personal problems $(54 \%$ each of Class 8 and Class 9 girls).

Table 4.10: Percentage of girls reporting access to a trusted adult at school to discuss personal problems and having solicited advice

\begin{tabular}{lcc}
\hline Access to and help sought from a trusted adult & Class $\mathbf{8}$ girls & Class $\mathbf{9}$ girls \\
\hline $\begin{array}{l}\text { Girls reporting the availability of a trusted adult in school with whom students } \\
\text { could discuss their personal problems }\end{array}$ & 54.0 & 54.4 \\
Number of respondents & $\mathbf{9 9 8}$ & $\mathbf{5 5 5}$ \\
Girls seeking advice from the person with whom students could discuss their & & 31.4 \\
personal problems in the month preceding the interview & 0.7 & 25.9 \\
Solicited and received advice & 67.9 & 7.2 \\
Solicited but did not receive advice & & 72.9 \\
Neither solicited nor received advice & $\mathbf{5 4 7}$ \\
Number of respondents who reported availability of a trusted person in & $\mathbf{3 2 6}$ \\
school with whom students could discuss their personal problems & & \\
\hline
\end{tabular}

Table 4.10 also shows that among girls who reported that students in their school had access to a trusted person they could turn to for discussing their personal problems, the vast majority had neither solicited nor received any advice in the month preceding the interview (68\% of Class 8 girls and $73 \%$ of Class 9 girls). Only 31 percent and 26 percent of Class 8 and Class 9 girls, respectively, reported soliciting and receiving advice from such a person.

\section{Teasing and harassment by fellow male students}

Girls' access to a safe environment in school is affected not only by the experience of corporal punishment, verbal harassment or sexual harassment perpetrated by teachers, but also by their own experiences of teasing or harassment perpetrated by fellow male students. Findings on experiences of teasing or harassment by fellow male students, presented in Table 4.11, show that a sizeable proportion of the girls who took the survey reported that male students do tease or harass female students in their school. Specifically, 29 percent and 18 percent of Class 8 
Table 4.11: Percentage of girls reporting teasing or harassment by fellow male students in their class/school, in the week preceding the interview

\begin{tabular}{lrr}
\hline Experience of harassment & Class $\mathbf{8}$ girls & Class $\mathbf{9}$ girls \\
\hline Girls who reported that boys in the class/school teased or harassed girls & $29.3 * * *$ & 17.5 \\
Girls who experienced teasing or harassment by boys at school & $5.2 * * *$ & 1.5 \\
Teachers punished boys in class who teased or harassed girls ${ }^{1}$ & 91.3 & 94.6 \\
Number of respondents attending mixed schools & $\mathbf{9 4 8}$ & $\mathbf{5 0 6}$ \\
\hline
\end{tabular}

Note: $* * *$ indicates that the difference in the means/distribution between Class 8 and Class 9 girls are significant at $p<.001 .{ }^{1 \%}$ of girls who reported that boys tease or harass fellow female students in the school.

and Class 9 girls, respectively, reported that boys in their class/school harassed girls. Fewer girls reported a personal experience of such teasing or harassment in the week prior to the interview ( $5 \%$ of Class 8 girls and $2 \%$ of Class 9 girls). Further, 91-95 percent of the girls who reported that fellow male students teased or harassed girls said that their teachers had punished boys who had engaged in such activities. 


\section{Chapter 5}

\section{Parental and community engagement in girls' education}

Findings related to parental and community engagement in the education of girls, as reported by girls who took the survey, are described in this chapter. Specifically, the chapter presents perceptions of surveyed girls about their parents' aspirations about their education and career and their parents' awareness of adolescent girls' entitlements from school. It also describes parental discussion about and engagement in their studies, and parental interactions with their school authorities. Also presented in the chapter are findings related to the perceptions of the surveyed girls about community engagement in support of girls' education, including their awareness of school management committees in their village and perceptions about the activities of panchayat members in support of girls' education.

\section{Parental aspirations about girls' education and career}

Several questions were posed to the girls in our study to assess their perceptions about their parents' aspirations about their education and careers. To explore gender differences in parental aspirations between sons and daughters, they were also asked about their parents' aspirations regarding their brother's education. The girls' responses are summarised in Table 5.1.

Several findings are notable. First, parental aspirations reported by Class 8 and Class 9 girls differed, with Class 9 girls reporting higher levels of parental aspirations as far as their education is concerned. For example, 17 percent of Class 8 girls reported that their parents would like them to complete 8 or 9 years of schooling compared to just three percent of Class 9 girls who reported that their parents would like them to discontinue after Class 9 . In contrast, 57 percent of Class 8 girls compared to 67 percent of Class 9 girls reported that their parents wanted them to complete Class 10 or Classes 11-12, and 15 percent of Class 8 girls compared to 20 percent of Class 9 girls reported that their parents wanted them to complete graduation and above or some professional courses. Second, girls' responses underscore gender differences in parental aspirations; according to the girls, parents were more likely to aspire for a higher level of schooling for their sons than daughters. For example, less than one percent of the girls, regardless of the class they attended, reported that their parents wanted their brother to complete less than Class 10, compared to 17 percent of Class 8 girls and three percent of Class 9 girls who reported that their parents would like them to complete less than Class 10.

We also probed the girls about the extent to which they thought their parents considered it important for them to complete Class 10 and to work for pay. As shown in Table 5.1, the majority of girls perceived that their parents considered it very important for them to complete Class 10 ( $72 \%$ of Class 8 girls and $84 \%$ of Class 9 girls); far fewer reported that their parents considered it very important for them to work for pay (53\% of Class 8 girls and $58 \%$ of Class 9 girls).

\section{Parental awareness of girls' entitlements from school}

The levels of parental awareness of student entitlements reported by the girls who took the survey were similar to their own awareness of these entitlements described in Chapter 4. Table 5.2, which presents these findings, shows that almost all girls-98 percent of Class 8 girls and 95 percent of Class 9 girls-reported that their parents were aware that students are entitled to receive free textbooks, and 97 percent and 96 percent of Class 8 and Class 9 girls, respectively, reported that their parents were aware that students are entitled to receive scholarships. Fewer girls-70 percent of Class 8 girls and 53 percent of Class 9 girls-said that their parents were aware that students are entitled to receive free uniforms. 
Table 5.1: Percent distribution of girls by perceived parental aspirations about their education and career

\begin{tabular}{|c|c|c|}
\hline Perceptions of parental aspirations & Class 8 girls & Class 9 girls \\
\hline \multicolumn{3}{|c|}{ Level of schooling that parents would like the girl to attain } \\
\hline Less than Class 10 & $17.2 * * *$ & 3.2 \\
\hline Class 10 & 32.6 & 37.2 \\
\hline Classes 11-12 & 24.2 & 29.6 \\
\hline Graduation and above & 12.3 & 17.2 \\
\hline Professional courses & 2.4 & 2.4 \\
\hline Non-specific responses & 7.7 & 6.8 \\
\hline Don't know & 3.3 & 3.6 \\
\hline \multicolumn{3}{|c|}{ Level of schooling that parents would like the girl's brother to attain } \\
\hline Less than Class 10 & $0.5 * * *$ & 0.0 \\
\hline Class 10 & 4.9 & 1.7 \\
\hline Classes 11-12 & 26.5 & 17.3 \\
\hline Graduation and above & 27.6 & 36.7 \\
\hline Professional courses & 2.3 & 3.7 \\
\hline Non-specific responses & 19.1 & 24.7 \\
\hline Don't know or no brother & 19.2 & 15.8 \\
\hline \multicolumn{3}{|c|}{ Perceptions about the importance of the girl completing Class 10 to her parents ${ }^{1}$} \\
\hline Not at all & $6.1 * * *$ & 1.0 \\
\hline Somewhat & 19.4 & 14.7 \\
\hline Very & 72.3 & 84.1 \\
\hline \multicolumn{3}{|c|}{ Perceptions about the importance of the girl working for pay to her parents ${ }^{2}$} \\
\hline Not at all & $6.8^{*}$ & 5.7 \\
\hline Somewhat & 37.5 & 36.2 \\
\hline Very & 53.1 & 57.6 \\
\hline Number of respondents & 999 & 559 \\
\hline
\end{tabular}

Note: ${ }^{*}$ and ${ }^{* *}$ indicate that differences in the means/distribution between Class 8 and Class 9 girls are significant at $p<.05$ and $p<.001$, respectively. ${ }^{1} 2 \%$ or fewer girls who reported that they were not aware of their parents' views are not shown in the table. 23\% or fewer girls who reported that they were not aware of their parents' views are not shown in the table.

Table 5.2: Percentage of girls reporting their parents' awareness of student entitlements

\begin{tabular}{lcc}
\hline Perceived parental awareness of entitlements & Class $\mathbf{8}$ girls & Class $\mathbf{9}$ girls \\
\hline Free textbooks & $97.7 * *$ & 94.7 \\
Free uniforms & $69.7 * * *$ & 52.8 \\
Scholarships & 97.2 & 96.4 \\
Number of respondents with one or both parents alive & $\mathbf{9 9 6}$ & $\mathbf{5 5 9}$ \\
\hline
\end{tabular}

Note: **and $* * *$ indicate that differences in the means/distribution between Class 8 and Class 9 girls are significant at $p<.01$ and $p<.001$, respectively.

\section{Parental discussion on girls' studies}

A series of questions were posed to the girls who took the survey to capture the extent of communication between them and their parents about their education. The girls were asked whether their mother and father had talked to them in the week prior to the interview about such topics as homework, performance in class, study materials, teachers and their behaviour with them, facilities in their school and their friends at school. Using the girls' responses, we created a summary index of recent communication between them and their parents about their 
studies. The girls were given a score of 1 for each topic that their mother and father discussed with them and 0 otherwise; the scores were then summed to create two indices, the value of which ranged from 0 indicating no recent communication on studies to 7 indicating a high level of recent communication. The indices were calculated separately for communication with mothers (Cronbach's alpha $=0.65$ for Class 8 girls and 0.63 for Class 9 girls) and communication with fathers (Cronbach's alpha $=0.68$ for Class 8 girls and 0.69 for Class 9 girls). Table 5.3 sums up these findings.

As seen in Table 5.3, recent discussion on girls' studies, that is, in the week prior to the interview, was limited; 52 percent of Class 8 girls and 59 percent of Class 9 girls reported that their mother had discussed their studies with them in the week prior to the interview; the corresponding percentages for such discussions with fathers were 42 and 46, respectively. Moreover, Class 8 girls and Class 9 girls each scored just one on a scale that ranged from 0 to 7 with respect to the number of topics related to their studies that their mother had discussed with them and less than one on a similar scale with respect to communication with their father. Findings also show that recent discussion on the girls' studies varied by the sex of the parent and the topic. Mothers were more likely than fathers to have discussed studies with their daughter; for example, 46 percent of Class 8 girls reported that their mother had talked to them about their homework compared to 33 percent who reported that their father had done so. Further, parents were more likely to discuss homework than their daughter's performance in class, facilities in their school, their teachers and their friends at school. For example, 46 percent of Class 8 girls and 48 percent of Class 9 girls reported that their mother had talked to them about their homework in the week prior to the interview; in contrast,

Table 5.3: Percentage of girls who reported discussing studies with their parents, in the week preceding the interview, by topic of discussion

\begin{tabular}{|c|c|c|}
\hline Topics of discussion & Class 8 girls & Class 9 girls \\
\hline \multicolumn{3}{|l|}{ Topics discussed by the girl and her mother } \\
\hline Homework & 45.8 & 48.3 \\
\hline Performance in the class & 9.8 & 11.5 \\
\hline Study materials & $8.8 * *$ & 13.4 \\
\hline Teachers & 10.9 & 12.6 \\
\hline Teachers' behaviour with the girl & 4.1 & 5.4 \\
\hline Facilities in school & 6.0 & 7.9 \\
\hline Friends in school & $10.8 * *$ & 15.8 \\
\hline At least one of the above topics & $52.4 *$ & 58.5 \\
\hline $\begin{array}{l}\text { Mean score, index of recent communication betw } \\
\text { studies (range } 0-7 \text { ) }\end{array}$ & $1.0 * *$ & 1.2 \\
\hline Number of respondents whose mother was alive & 979 & 550 \\
\hline \multicolumn{3}{|l|}{ Topics discussed by the girl and her father } \\
\hline Homework & 32.9 & 35.9 \\
\hline Performance in the class & 10.0 & 9.8 \\
\hline Study materials & 12.7 & 11.8 \\
\hline Teachers & $8.6 *$ & 12.1 \\
\hline Teachers' behaviour with the girl & 4.3 & 4.7 \\
\hline Facilities in school & 4.5 & 5.2 \\
\hline Friends in school & 4.0 & 5.8 \\
\hline At least one of the above topics & 41.9 & 45.9 \\
\hline $\begin{array}{l}\text { Mean score, index of recent communication betw } \\
\text { studies (range } 0-7 \text { ) }\end{array}$ & 0.8 & 0.9 \\
\hline Number of respondents whose father was alive & 978 & 544 \\
\hline
\end{tabular}

Note: ${ }^{*}$ and $* *$ indicate that differences in the means/distribution between Class 8 and Class 9 girls are significant at $p<.05$ and $p<.01$, respectively. 
no more than 11 percent of Class 8 girls and no more than 16 percent of Class 9 girls reported that their mother had talked to them about such matters as their performance in class, study materials, their teachers and the teachers' behaviour with them, facilities in their school and their friends at school. Similar findings were observed in the case of fathers, with 33 percent and 36 percent of Class 8 and Class 9 girls, respectively, reporting that their father had talked to them about homework in the week prior to the interview; in contrast, no more than 13 percent of Class 8 girls and no more than 12 percent of Class 9 girls reported that their father had discussed any other topic related to their studies with them during that week.

\section{Time spent by parents in supporting their daughter's education}

Several indicators were used to measure the extent to which girls reported that their parents spent time in encouraging their educational pursuits. The girls who took our survey were asked: (1) how often their parents had spent time with them on their studies in the week prior to the interview, that is, in helping them with their studies, giving them company when they did their homework, or escorting them to school; and (2) the amount of time their parents had spent in providing such support to them. Their responses are summarised in Table 5.4.

Findings show that the practice of spending time on their daughter's studies was limited among parents. Indeed, only 53-54 percent and 44-47 percent of the girls reported that their mother and father, respectively, had spent time with them on their studies in the week preceding the interview. The girls were most likely to report that their parents had spent time in keeping them company while they were doing their homework and least likely to report that their parents had spent time in escorting them to school. For example, 51-53 percent and 40-42 percent of the girls reported that their mother and father, respectively, spent time in keeping them company while they were doing their homework, while 1-2 percent and 3-4 percent reported that their mother and father, respectively, spent time in escorting them to school, corroborating the finding that two percent and six percent commuted to school in their own vehicle (Chapter 4) The kind of supportive activity in which mothers and fathers spent time with their daughters on their studies also differed. Mothers were less likely than fathers to help girls in doing their homework (9-12\% versus $19-24 \%)$, while they were more likely than fathers to keep them company while they did so (51-53\% versus 40-42\%); these findings, perhaps, reflect the educational differences between mothers and fathers described in

Table 5.4: Percentage of girls reporting that their parents spent time with them on their studies in the week preceding the interview, by type of support received

\begin{tabular}{|c|c|c|}
\hline Type of parental support to daughter & Class 8 girls & Class 9 girls \\
\hline \multicolumn{3}{|l|}{ Mother spent time with the girl by } \\
\hline Helping with her homework & 11.9 & 8.6 \\
\hline Keeping her company while doing homework & 51.1 & 53.4 \\
\hline Escorting her to school & 1.9 & 0.7 \\
\hline In any one of the above activities & 53.4 & 53.7 \\
\hline $\begin{array}{l}\text { The amount of time spent by the mother on her daughter's studies in the pre-interview } \\
\text { week (mean number of hours) }\end{array}$ & 1.6 & 1.9 \\
\hline Number of respondents whose mother was alive & 979 & 550 \\
\hline \multicolumn{3}{|l|}{ Father spent time with the girl by } \\
\hline Helping with her homework & $24.1 *$ & 18.5 \\
\hline Keeping her company while doing homework & 41.8 & 39.5 \\
\hline Escorting her to school & 2.6 & 3.7 \\
\hline In any one of the above activities & 46.5 & 44.2 \\
\hline $\begin{array}{l}\text { The amount of time spent by the father on his daughter's studies in the pre-interview week } \\
\text { (mean number of hours) }\end{array}$ & 3.2 & 3.0 \\
\hline Number of respondents whose father was alive & 978 & 544 \\
\hline
\end{tabular}

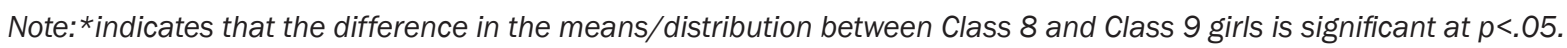


Chapter 1. As regards the amount of time spent by parents on these supportive activities during the pre-interview week, Class 8 and Class 9 girls reported that their mothers spent, on average, 1.6 hours and 1.9 hours, respectively; they reported that much more time was so spent by their fathers-three hours each. While these numbers suggest considerable parental support to daughters' studies, we note that keeping the daughter company while she is studying denotes, at best, a passive form of support.

\section{Parental interactions with school authorities}

The study also assessed the interactions of parents with the authorities of their daughter's school by probing the girls who took the survey about whether, to their knowledge, their parents had visited their school in the month preceding the interview and, if so, the number of times they had visited and the purpose of visiting the school; it also probed their parents' attendance at parent-teacher meetings and parental discussion with teachers about their daughter's performance. The findings, presented in Table 5.5, show that parents of 37 percent of Class 8 girls and 34 percent of Class 9 girls had visited their daughter's school in the month preceding the interview. Among girls who so reported, their parents had visited their school 1.8-1.9 times, on average. We caution that the survey was fielded one-and-a-half to two-and-a-half months after the beginning of the current academic year, and therefore, the average

Table 5.5: Percentage of girls reporting that their parents had visited their school, in the month preceding the interview, by purpose of visit

\begin{tabular}{|c|c|c|}
\hline Purpose of parents' visit & Class 8 girls & Class 9 girls \\
\hline Girl's mother or father visited her school & 37.4 & 34.3 \\
\hline Number of times girl's parents visited her school & 1.8 & 1.9 \\
\hline \multicolumn{3}{|l|}{ Purpose of parental visit } \\
\hline To enroll the girl (daughter) in school & - & 4.4 \\
\hline To pay the school fees & 0.9 & 2.0 \\
\hline Admission-related & $0.9 * * *$ & 6.4 \\
\hline Procuring study materials related & 0.9 & 3.6 \\
\hline To meet their daughter's teachers & 68.7 & 64.8 \\
\hline To attend parent-teacher meetings & 13.2 & 12.6 \\
\hline To attend a programme in school & 0.6 & 0.0 \\
\hline Interacting with teachers related & 78.1 & 71.3 \\
\hline To fulfill formalities for availing of entitlements & 25.6 & 26.7 \\
\hline To collect scholarship money & 0.7 & 0.0 \\
\hline Availing entitlement related & 26.3 & 26.7 \\
\hline Other & 0.6 & 1.2 \\
\hline Number of respondents whose parents visited the school & 359 & 185 \\
\hline \multicolumn{3}{|c|}{ Parents attended parents-teachers' meetings in the month preceding the interview } \\
\hline Yes & 8.7 & 6.4 \\
\hline No & 2.3 & 1.9 \\
\hline No meeting held in school & 89.0 & 91.7 \\
\hline \multicolumn{3}{|c|}{$\begin{array}{l}\text { Girl's parents talked to her teachers about her performance in the month preceding } \\
\text { the interview }\end{array}$} \\
\hline Yes & 30.6 & 30.9 \\
\hline No & 63.0 & 61.9 \\
\hline Don't know & 6.5 & 7.2 \\
\hline Number of respondents with one or both parents alive & 996 & 559 \\
\hline
\end{tabular}

Note: $* *$ indicates that the difference in the means distribution between Class 8 and Class 9 girls is significant at $p<.001$, respectively. 
number of times that parents had reportedly visited the school may have been due to admission-related reasons and, as such, may not necessarily reflect what typically goes on during the school year. Girls who reported that their parents had visited their school in the month preceding the interview mentioned that it was mainly to meet their teachers, or to attend a parent-teacher meeting or a programme in school as reported by 78 percent of Class 8 girls and 71 percent of Class 9 girls whose parents had visited the school at least once that month. Another commonly cited reason for these parental visits related to availing of girls' entitlements from the school, reported by 26-27 percent of Class 8 and Class 9 girls.

Table 5.5 also shows that parent-teacher meetings were rarely organised in schools; while 89-92 percent of the girls reported that no parent-teacher meeting had been held in their school in the month preceding the interview, some 6-9 percent of girls reported that their parents had attended a parent-teacher meeting during that month. Moreover, 31 percent each of both Class 8 and Class 9 girls said that their parents had discussed their performance with their teachers during their visit.

\section{Parental financial investments in girls' education}

Financial investments made by parents in their daughter's education, as reported by the girls who took the survey, were measured by using two indicators-providing private tuition to the girl and the amount of money parents or others in the family spent on the girl's studies in the month preceding the interview. The findings, shown in Table 5.6, indicate that private tuitions were arranged for only a small minority of girls-six percent each of Class 8 and Class 9 girls.

Table 5.6: Percentage of girls reporting financial investments by parents in their education in the month preceding the interview, by item of expenditure

\begin{tabular}{|c|c|c|}
\hline Items of expenditure & Class 8 girls & Class 9 girls \\
\hline Fees for private tuition for the girl & 5.5 & 5.5 \\
\hline \multicolumn{3}{|l|}{ Amount of money spent on the girl's studies (mean INR) } \\
\hline School fees ${ }^{1}$ & $12.00 * * *$ & 39.00 \\
\hline Textbooks and notebooks ${ }^{2}$ & $98.00 * * *$ & 190.00 \\
\hline Other supplies ${ }^{3}$ & 25.00 & 31.00 \\
\hline Uniforms ${ }^{4}$ & $33.00 * * *$ & 100.00 \\
\hline Transportation $^{5}$ & $7.00 * * *$ & 94.00 \\
\hline Private tuition 6 & 5.00 & 12.00 \\
\hline Any other items ${ }^{7}$ & $51.00 * * *$ & 69.00 \\
\hline Average amount spent in the month preceding the interview & $212.00 * * *$ & 500.00 \\
\hline Number of respondents & 999 & 559 \\
\hline
\end{tabular}

Note: $* *$ indicates that the differences in the means/distribution between Class 8 and Class 9 girls is significant at $p<.001$.

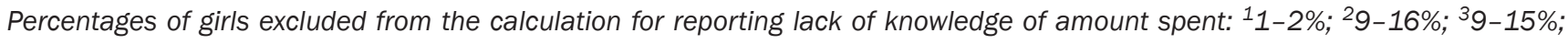
${ }^{4} 3-5 \% ;{ }^{5} 2 \%$ or fewer; ${ }^{6}$ less than $1 \% ;{ }^{7} 1-5 \%$.

Findings, however, show that parents and other family members had spent a substantial amount on the girls' education in the month preceding the interview, part of which may be explained by the fact that the survey was conducted soon after the beginning of the academic year when expenses on fees, school supplies and so on are generally incurred. Parents spent, on average, Rs. 212 on studies for Class 8 girls and Rs. 500 for Class 9 girls.

Table 5.6 further shows that the item on which parents spent most was textbooks and notebooks, followed by uniforms: on average, Rs. 98 and Rs. 190 on textbooks and notebooks, and Rs. 33 and Rs. 100 on uniforms, for Class 8 and Class 9 girls, respectively. For Class 9 girls, in addition, they spent, on average, Rs. 94 for transportation. Such items as school fees, other school supplies and private tuition cost between Rs. 5 and Rs. 25 for Class 8 girls and between Rs. 12 and Rs. 39 for Class 9 girls. It is notable that such recurring expenses as school fees, transportation and other unspecified items cost Rs. 69 for Class 8 girls and Rs. 200 for Class 9 girls, and the difference was largely related to the cost of transportation. 


\section{Girls' awareness of school management committees}

Although school management committees, statutory bodies established by the government to promote enrolment, retention and achievement of children in primary schools and to make schools effective, are mandatory under the Right to Education Act, 19-23 percent of girls reported that no such committee existed in their school and another 65-68 percent of girls reported that they were not sure whether such committees existed in their school or village. Just 13 percent each of Class 8 and Class 9 girls reported awareness of such committees (Table 5.7).

Table 5.7: Percent distribution of girls by awareness of school management committees

\begin{tabular}{lcc}
\hline Awareness of school management committees & Class $\mathbf{8}$ girls & Class $\mathbf{9}$ girls \\
\hline Existence of school management committee in the girl's village/school & & \\
Yes & 12.8 & 12.7 \\
No & 22.7 & 19.4 \\
Not sure & 64.5 & 67.9 \\
Number of respondents & $\mathbf{9 9 9}$ & $\mathbf{5 5 9}$ \\
\hline
\end{tabular}

\section{Girls' perceptions about the engagement of panchayat members in girls' education}

The study also assessed girls' perceptions about the engagement of the members of their village panchayat in promoting girls' education. Girls who took the survey were probed about whether the panchayat members in their village took any initiative in promoting girls' education, for example, talking to parents if their daughters discontinued schooling, and negotiating with schools if facilities were lacking in the school and if teachers were absent.

Table 5.8: Percent distribution of girls by perceived engagement of panchayat members in promoting girls' education

\begin{tabular}{lcc}
\hline Perceived initiatives of panchayat members & Class $\mathbf{8}$ girls & Class $\mathbf{9}$ girls \\
\hline Panchayat member usually talks to parents if their daughters discontinue education & 15.0 & 14.4 \\
Yes & 60.0 & 58.3 \\
No & 25.0 & 27.3 \\
Don't know & 30.9 & 31.2 \\
Panchayat member negotiates with the school if facilities are lacking & 42.5 & 41.1 \\
Yes & 26.6 & 27.7 \\
No & & 10.7 \\
Don't know & 57.6 \\
Panchayat member negotiates with the school if teachers are absent & 31.7 \\
Yes & $\mathbf{9 9 9}$ \\
No & 57.4 \\
Don't know & 31.6 & $\mathbf{5 5 9}$ \\
Number of respondents & 3 \\
\hline
\end{tabular}

As shown in Table 5.8, only a small proportion of girls reported the engagement of panchayat members in these tasks. Specifically, just 14-15 percent of girls believed that a panchayat member did usually talk to parents if their daughter had discontinued schooling. Likewise, just 11 percent each of Class 8 and Class 9 girls thought that panchayat members would negotiate with the school if teachers were absent, and a slightly larger and equal proportion of girls reported that panchayat members would negotiate with schools if they lacked facilities (31\% each of Class 8 and Class 9 girls). 


\section{Chapter 6 \\ Summary and conclusions}

The major findings of the baseline assessment of the school experiences of the adolescent girls who took our survey, and the family, school and community environments in which they pursued their studies are encapsulated in this chapter.

\section{A. Girls' school experiences were compromised}

The findings presented in this report highlight that girls' school experiences were compromised, as summarised below.

Class attendance was far from regular for sizeable proportions of girls and absenteeism was attributed largely to domestic chores, engagement in paid or unpaid work and family functions

Although the majority of the girls in our study attended school regularly, that is, attended on all the days when the school was in session in the week prior to the interview, it is notable that more than one-quarter had missed one or more school days in the week prior to the interview. Moreover, one in eight girls from both Class 8 and Class 9 had missed school continuously for one week or more during the current academic year. Irrespective of the number of days missed, the girls mainly cited household-related reasons such as domestic chores, engagement in paid or unpaid work and family functions. Findings also show that only a minority of Class 8 girls attributed school absences to reasons related to difficulties in travelling to and from school; however, notable proportions of Class 9 girls listed transportation-related reasons.

\section{Girls' academic performance was abysmally poor}

Findings underscore the extremely poor academic performance of the survey participants. Class 8 girls scored, on average, 26 percentage marks in solving Class 7 Mathematics problems, and Class 9 girls scored, on average, 21 percentage marks in solving Class 7 and Class 8 Mathematics problems. In English comprehension and sentence construction too, both Class 8 and Class 9 girls performed very poorly. For example, Class 8 girls scored, on average, 12 and nine percentage marks for comprehension and sentence construction, respectively, while Class 9 girls scored 11 and nine percentage marks, respectively. Finally, although the girls performed better in the Gujarati than in the English language competency test, their performance in Gujarati was also far from satisfactory: on average, Class 8 girls scored 39 and 36 percentage marks for comprehension and sentence construction, respectively, and Class 9 girls scored 38 and 36 percentage marks, respectively. Findings also show that girls who regularly attended school scored better in all three tests than their counterparts who missed class.

\section{B. Girls' perceived ability to realise their aspirations was limited}

Findings underscore the limited perceived ability of the survey participants to realise their educational aspirations, as summarised below.

Most girls displayed aspirations about completing at least a secondary education, but somewhat fewer displayed aspirations about working after completing their studies

Findings note that the vast majority of the girls who took the survey aspired to complete at least a secondary education. Indeed, 61 percent of Class 8 girls and 58 percent of Class 9 girls wanted to complete Class 10 or Classes 11-12, and 27 percent and 35 percent, respectively, wanted to obtain a bachelor's degree or better, or complete a professional course. Relatively fewer girls highly valued working for pay after completing their studies-68 percent of Class 8 girls and 73 percent of Class 9 girls, and even fewer so valued working outside their home after completing their studies-43 percent of Class 8 girls and 50 percent of Class 9 girls. 


\section{Many girls expressed a lack of confidence in their ability to realise their aspirations and adhered to gender inegalitarian norms}

Findings show that notable proportions of the survey participants expressed a lack of confidence in their ability to realise their educational aspirations. Only 66 percent of Class 8 girls and 77 percent of Class 9 girls were fully confident of their ability to attend classes and perform well, that is, they felt that they would be able to attend school regularly, that the school lessons were easy for them to learn, and that they would be able to get good marks in their examinations. Findings also show that for a notable proportion of girls, the number of years of schooling that they thought they would be able to complete fell short of what they aspired to complete, indicating their perceived inability to realise their educational aspirations. Indeed, 29 percent each of Class 8 girls and Class 9 girls perceived that they may not be able to realise their educational aspirations under their current circumstances. Most prominent among the reasons for these perceptions were such household-related reasons as inability to afford the cost of studies, parental disapproval, plans for marriage, and lack of time due to household chores or wage work. School-related reasons, particularly lack of a school for further studies in their village were also frequently mentioned. Indeed, one-third of Class 8 girls and one-fifth of Class 9 girls who perceived that they could not realise their educational aspirations cited both household- and school-related reasons.

Closely related to the perceived inability of the surveyed girls to realise their educational aspirations was their limited agency, in general. Just 37 percent of Class 8 girls and 46 percent of Class 9 girls reported that they would have a say in decisions related to the level of schooling that they should have. Likewise, their ability to negotiate with their parents regarding their education and career if their parents' opinion differed from their own opinion was limited. Just 50 percent of Class 8 girls and 55 percent of Class 9 girls reported that if their parents' opinion differed from their own, they would convince their parents or go against their parents' wishes with regard to their schooling. Girls' communication skills were also limited; just 57-59 percent of girls displayed confidence in their ability to communicate their opinions without any discomfort. Finally, many girls adhered to gender inegalitarian norms. For example, girls' perceptions about the level of schooling that girls and boys should have were clearly gendered; the proportion of girls who suggested Class 10 as the ideal level of schooling for girls was much larger than the proportion suggesting this level was ideal for boys: 21 percent and three percent, respectively, of Class 8 girls, and 15 percent and one percent, respectively, of Class 9 girls. In contrast, the proportion of girls who reported the completion of a Bachelor's degree and above or a professional course as the ideal level of schooling was larger for boys than for girls-51 percent versus 28 percent among Class 8 girls and 61 percent versus 41 percent among Class 9 girls. Perceptions of girls about the ability of boys and girls to learn different subjects like Mathematics, and the English and Gujarati languages were also gendered, with many girls perceiving that boys perform better than girls. Likewise, only 69 percent of Class 8 girls and 77 percent of Class 9 girls believed that educating girls is as important as educating boys.

\section{Many girls combined studies and work on a daily basis}

Time use data show that on their last school day, Class 8 girls and Class 9 girls spent, on average, 7.5 hours and 7.9 hours, respectively, on school-related activities, that is, in school, in doing homework and commuting between school and home. We note, however, that available data do not allow us to distinguish the amount of time that girls devoted to studies compared to that devoted to non-academic chores. They spent, on average, almost three hours on work, most of which comprised household chores. Finally, they enjoyed, on average, two hours of leisure time.

\section{The school environment was, by and large, far from supportive in enabling girls to pursue their studies}

\section{Most girls reported easy physical access to school}

Findings suggest that Class 8 girls took, on average, 12 minutes to reach their school and Class 9 girls, 21 minutes. While almost all Class 8 girls went to school on foot, relatively fewer Class 9 girls (68\%) did so. In general, the majority of girls felt safe; for example, 92 percent of Class 8 girls and 85 percent of Class 9 girls reported that they always felt safe on their way to school. Indeed, no more than a negligible minority of Class 8 girls (3\%) and somewhat 
more Class 9 girls (14\%) reported that they had experienced any difficulty in commuting to school in the current academic year, including with regard to public transportation, harassment on the way, poor road conditions and bad weather.

\section{Inadequate infrastructure and limited number of teachers characterised most schools attended by the study participants}

School infrastructure was inadequate on several counts. For example, such facilities as a library, laboratory facilities and separate girls' toilets were not universally available even at the high school level. Indeed, just a little over a quarter of Class 8 girls and fewer than one-half of Class 9 girls reported that their school had all the amenities explored in the study-comfortable classrooms, a library, laboratory facilities, drinking water facilities, a separate toilet for girls and playgrounds. Findings also show that a sizeable proportion of girls, particularly Class 8 girls, attended schools with just 1-2 teachers-17 percent of Class 8 girls and ten percent of Class 9 girls.

\section{Although the majority of girls were aware of entitlements from school, their awareness was superficial and utilisation of entitlements was limited}

Most of the surveyed girls-over 90\%-reported awareness of such entitlements from the school as free textbooks and scholarships. Somewhat fewer girls-74 percent of Class 8 girls and 57 percent of Class 9 girls-reported that students are entitled to free uniforms. Although almost all girls had heard about scholarships, in-depth awareness was limited; less than one percent of girls mentioned correctly the name of at least one scholarship, and just one-fifth were able to correctly identify the eligibility criteria and the amount of money awarded for at least one scholarship. Findings also show the limited utilisation of these entitlements, particularly in the case of uniforms and scholarships. The most-utilised entitlement was free textbooks, claimed by 98 percent of Class 8 girls and 75 percent of Class 9 girls. In contrast, just 6-7 percent of Class 8 girls and one percent of Class 9 girls had obtained free uniforms and scholarships during the current academic year. Findings, moreover, show that only a few girls had received scholarships even among those from socially and economically disadvantaged population groups.

\section{Absenteeism among teachers was considerable and classroom dynamics was mixed}

Notable proportions of the girls who took our survey reported that at least one of their teachers had been absent at least one day in the week prior to the interview-37 percent of Class 8 girls and 45 percent of Class 9 girls.

Sizeable proportions of girls-79 percent of Class 8 girls and 77 percent of Class 9 girls-reported that their teachers had provided positive feedback to students, that is, praised students when they did well in class in the week prior to the interview. Likewise, over 90 percent of girls reported that their teachers had not discriminated against students on any grounds. Similarly, the majority of girls reported that their teachers had conveyed egalitarian gender role attitudes-73 percent of Class 8 girls and 80 percent of Class 9 girls so reported.

At the same time, one-fifth of the girls reported that their teachers had not given positive feedback to students when they did well in class in the week prior to the interview. Moreover, disturbing proportions of girls (44-49\%) reported that their teachers had scolded students when they did not understand their lessons or had called them "stupid". One-quarter of Class 8 girls and one-fifth of Class 9 girls said that their teachers had conveyed gender inegalitarian attitudes in the classroom, that is, had made comments that implied that boys should concentrate on studies as it is they who will have to take care of family responsibilities, or girls should be helping their mothers at home instead of wasting their time at school.

Moreover, almost one-fifth of Class 8 girls and one-seventh of Class 9 girls had experienced at least one form of harassment at the hands of their teachers in the week prior to the interview. While only a minority of girls had experienced corporal punishment-six percent of Class 8 girls and five percent of Class 9 girls-or sexual harassment-less than two percent and one percent of Class 8 and Class 9 girls, respectively, verbal harassment was reported by 15 percent of Class 8 girls and ten percent of Class 9 girls.

The vast majority of the surveyed girls, particularly those attending Class 8 were involved in a number of chores in the school in the week prior to the interview; 89 percent of Class 8 girls and 52 percent of Class 9 girls reported having performed such chores as cleaning classrooms and school toilets, gardening, fetching water, preparing meals 
in the school, and running errands for and assisting teachers at their home. Although the chores that girls frequently undertook included cleaning classrooms and gardening, sizeable proportions of Class 8 girls were engaged in such chores as running errands for the teachers, fetching water, and cleaning school toilets.

\section{The majority of girls reported access to a trusted adult at school with whom students could discuss personal problems, but few solicited and received her/his advice}

One-half or more survey participants reported the availability of a trusted adult in their school with whom students could discuss their personal problems. However, of girls who reported access to such a person in their school, only one-third of Class 8 girls and one-quarter of Class 9 girls said that they had solicited and received advice from the person.

\section{Sizeable proportions of girls reported harassment and teasing by fellow male students}

Substantial proportions of girls reported that male students teased or harassed female students in their school-29 percent of Class 8 girls and 18 percent of Class 9 girls so reported. However, fewer girls reported any such personal experience in the week preceding the interview-five percent and two percent of Class 8 and Class 9 girls, respectively. Of girls who reported such problems, 91-95 percent stated that their teachers punished boys who teased or harassed girls.

\section{Parental engagement in support of their daughter's education was, at best, modest}

Findings show that parental support for their daughter's education was, at best, modest, as summarised below.

\section{Parents' educational aspirations for their children were gendered}

Most, but not all the surveyed girls, perceived that their parents wanted them to complete at least a secondary education; 72 percent of Class 8 girls and 86 percent of Class 9 girls reported that their parents wanted them to complete Class 10, Classes 11-12, graduation and above or some professional courses. At the same time, they perceived that their parents were more likely to aspire for a higher level of schooling for their brothers than for themselves. For example, less than one percent of the girls reported that their parents wanted their brother to complete less than Class 10, compared to 17 percent of Class 8 girls and three percent of Class 9 girls who reported that their parents would like them to discontinue after Class 9.

\section{Parental communication and interaction with daughters regarding their education was somewhat limited, but financial investment was considerable}

Findings show that parental communication with girls about their studies was somewhat limited; only 52 percent of Class 8 girls and 59 percent of Class 9 girls reported that their mother had discussed their studies with them in the week prior to the interview; likewise, 42 percent and 46 percent of Class 8 and Class 9 girls, respectively, reported that their father had done so during that week. Parents were more likely to discuss homework than their daughter's performance in class, facilities in her school, her teachers or her friends at school. Indeed, Class 8 girls and Class 9 girls each scored just one on a scale that ranged from 0 to 7 with respect to the number of topics related to their studies that their mother had discussed with them and less than one on a similar scale with respect to communication with their father on these topics.

Moreover, not all parents spent time with their daughters on their studies; only 53-54 percent and 44-47 percent of the girls in our survey reported that their mother and father, respectively, had spent time with them on their studies in the week prior to the interview. The girls were most likely to report that their parents had spent time in keeping them company while they were doing their homework and least likely to report that their parents had spent time in escorting them to school. The type of activity in which mothers and fathers had spent time with their daughters also differed. Mothers were less likely than fathers to help their daughters with their homework, while they were more likely to keep them company while they were doing their homework. In the week prior to the interview, mothers had spent, on average, 1.6 hours and 1.9 hours in supporting the studies of Class 8 and Class 9 girls, respectively; in comparison, much more time was spent by fathers-three hours each reported by Class 8 and Class 9 girls. 
Findings also show that private tuitions were arranged for only a small minority of girls-six percent each of Class 8 and Class 9 girls. Finally, findings show that parents and other family members had spent a substantial amount on the girls' education in the month preceding the interview, part of which may be explained by the fact that the survey was conducted soon after the beginning of the academic calendar. Parents of Class 8 and Class 9 girls had spent, on average, Rs. 212 and Rs. 500, respectively, on the education of their daughters. The item on which parents spent most was textbooks and notebooks, followed by uniforms. It is notable that recurring expenses were incurred to the tune of Rs. 69 for Class 8 girls and Rs. 200 for Class 9 girls, and that the difference was largely due to the cost of transportation.

\section{Parental interaction with school authorities was limited}

Findings show that parents of 37 percent of Class 8 girls and 34 percent of Class 9 girls had visited their daughter's school in the month preceding the interview. Among girls who so reported, parents had visited their school on average 1.8-1.9 times; the purpose of these visits included meeting their teachers, and more rarely, attending a parent-teacher meeting or a programme in school.

Findings also show that parent-teacher meetings were rarely organised by schools; 89-92 percent of girls reported that no parent-teacher meeting had been held in their school in the month preceding the interview. Just 31 percent each of Class 8 and Class 9 girls reported that their parents had discussed their performance with one or more teachers in the month preceding the interview.

\section{E. Community engagement in support of girls' education was limited or unknown to girls}

Findings also show that community engagement in support of girls was limited or unknown to the girls who took our survey. Although school management committees are mandatory under the Right to Education Act, just 13 percent each of Class 8 and Class 9 girls reported awareness of such committees, while others reported that no such committees existed in their school or that they were not sure whether such committees existed in their school or village. Moreover, only a small proportion of girls reported that the panchayat members in their village took any initiative in promoting girls' education, for example, talking to parents if their daughters had discontinued their schooling, and negotiating with schools for facilities that were lacking or for reducing teacher absenteeism.

In short, study findings underscore the irregular attendance, poor performance and limited educational and career aspirations of school-going girls, the limited priority that parents give to girls' education, and the limited support that girls receive from their parents, their teachers and their communities in overcoming obstacles to schooling and the learning. At the same time, a commonly held perception that schooling is discontinued because of concerns about long distances to be travelled to school and the safety of girls appear to be unfounded from the perspectives of girls. Findings clearly support a focus on enhancing parental and community engagement in girls' schooling, and a need to strengthen ways through which parents and communities may hold school systems and teachers accountable for ensuring more regular teacher and student attendance in school, adequate infrastructure, as well as better quality teaching and improved learning outcomes. 


\section{Annexure 1 \\ Details of the household wealth index}

Household economic status was measured using a wealth index composed of household asset data on ownership of selected durable goods, including means of transportation, as well as data on access to a number of amenities. The wealth index was constructed by allocating the following scores to a household's reported assets or amenities:

Type of house: 2 for pucca; 1 for semi-pucca; 0 for kachcha

Agricultural land owned: 4 for more than 10 acres; 3 for 5.1-10.0 acres; 2 for 2.6-5.0 acres; 1 for less than 2.6 acres, or if the household owns some land but does not know how much; 0 for no land

Irrigated land owned: 1 for any irrigated land; 0 for no land

Access to a toilet facility: 4 for own toilet; 2 for shared toilet; 0 for no toilet facility

Cooking fuel used: 2 for liquid petroleum gas, electricity or bio-gas; 1 for kerosene, wood, crop residue, dung cakes, coal or charcoal; 0 for other types of cooking fuel, for example, straw, shrubs or grass

Access to a drinking water facility: 4 for own piped water, hand-pump or covered well; 3 for own open well; 2 for public or shared piped water, hand-pump or covered well; 1 for public or shared open well; 0 for other sources of drinking water, for example, surface water, tanker/truck or rainwater

Access to electricity: 3 for electricity; 0 for no electricity

Ownership of household assets: 4 for car, truck, thresher or tractor; 3 each for motorcycle or scooter, refrigerator, computer/laptop, telephone (landline or mobile), colour television; 2 each for bicycle, electric fan, radio or transistor, black and white television, sewing machine, water pump; 1 for watch or clock; 0 for each of the above items that the household does not possess.

Index scores, so constructed, ranged from 0 to 52. 


\section{References}

ASER Centre. 2012. Annual status of education report (Rural) 2011 Provisional. New Delhi: ASER.

Banerjee, A. V., R. Banerji, E. Duflo et al. 2006. "Can Informational Campaigns Spark Local Participation and Improve Outcomes: A Study of Primary Education in Uttar Pradesh, India," World Bank Policy Research Working Paper 3967.

Banerjee, A. V., R. Banerji., E. Duflo et al. 2010. "Pitfalls of Participatory Programs: Evidence from a Randomized Evaluation in Education in India." American Economic Journal: Economic Policy, American Economic Association, 2(1): 1-30.

Commissionerate of Schools, Government of Gujarat, n.d, a. Programme. Accessed on 11 June, 2014 at http://cos.gujarat.gov. in/programme.htm.

Commissionerate of Schools, Government of Gujarat, n.d, b. Schemes. Accessed on 11 June, 2014 at http://cos.gujarat.gov.in/ schemes.htm.

Dhaliwal, I., E. Duflo, R. Glennerster et al. 2011. Comparative Cost-Effectiveness Analysis to Inform Policy in Developing Countries: A General Framework with Applications for Education. Accessed on 10 March, 2014 at http://www.povertyactionlab.org/ publication/cost-effectiveness.

International Institute for Population Sciences (IIPS) and Macro International, 2007. National Family Health Survey (NFHS-3), 2005-2006: India: Volume 1. Mumbai: IIPS.

International Institute for Population Sciences (IIPS). 2010. District Level Household and Facility Survey (DLHS-3), 2007-08: India. Mumbai: IIPS.

International Institute for Population Sciences (IIPS) and Population Council, 2010. Youth in India: Situation and Needs 20062007. Mumbai: IIPS.

Jensen, Robert. 2010. “The (perceived) returns to education and the demand for schooling." The Quarterly Journal of Economics, 125(2): 515-48.

Lloyd, C. 2009. New lessons the power of educating adolescent girls: A girls count report on adolescent girls. New York: Population Council.

Ministry of Human Resource Development (MOHRD). 2009. Framework for implementation of Rashtriya Madhyamik Shiksha Abhiyan. New Delhi: MOHRD, Government of India. Accessed on 12 March, 2014 at http://mhrd.gov.in/sites/upload_files/ mhrd/files/Framework_Final_RMSA_3.pdf.

Ministry of Human Resource Development (MOHRD). 2011a. Working Group Report on Secondary and Vocational Education 12th Five Year Plan 2012-2017. New Delhi: Department of School Education and Literacy, MOHRD, Government of India.

Ministry of Human Resource Development (MOHRD). 2011b. Statistics of school education, 2009-2010. New Delhi: Ministry of Human Resource Development. Accessed on 10 March, 2014 at http://mhrd.gov.in/sites/upload_files/mhrd/files/SESSchool_200910F.pdf.

Ministry of Human Resource Development (MOHRD). 2014. Statistics of School Education 2010-11. New Delhi: Bureau of Planning, Monitoring and Statistics, MOHRD, Government of India.

Ministry of Statistics and Programme Implementation (MOSPI). 2012. Statement: Gross State Domestic Product at Current Prices. Accessed on 12 March, 2014 athttp://mospi.nic.in/Mospi_New/upload/State_wise_SDP_2004-05_14mar12.pdf.

Ministry of Youth Affairs and Sports (MOYAS). 2014. National Youth Policy 2014. New Delhi: MOYAS, Government of India.

Nguyen, Trang. 2008. Information, Role Models and Perceived Returns to Education: Experimental Evidence from Madagascar. Massachusetts Institute of Technology Working Paper, Cambridge, MA: MIT.

Office of the Registrar General and Census Commissioner, India. n.d, a. Census of India 2011: A-5 STATE PRIMARY CENSUS ABSTRACT - 2011. Accessed on 21 April, 2014 at http://www.censusindia.gov.in/2011census/hlo/pca/pca_pdf/PCACRC-2400.pdf. 
Office of the Registrar General and Census Commissioner, India. n.d.,b. Census of India 2011: HH-12: number of households availing banking services and number of households having each of the specified assets. Accessed on $25 \mathrm{March}, 2014$ at http://www.censusindia.gov.in/2011census/hlo/District_Tables/Distt_table/24/HH4012-2400DCRC.pdf.

Office of the Registrar General and Census Commissioner, India. n.d., c. Census of India 2011: Five Year Age Group Data - C14 Table, Gujarat. New Delhi: Office of the Registrar General and Census Commissioner India.

Office of the Registrar General and Census Commissioner, India. 2012. Houses Household Amenities and Assets-Communication. Accessed on 25 March, 2014 athttp://www.censusindia.gov.in/2011census/hlo/Data_sheet/India/Communication.pdf.

Office of the Registrar General and Census Commissioner, India. 2013. Primary Census Abstract, Data Highlights, India, Series 1. New Delhi: Office of the Registrar General and Census Commissioner, India. Accessed on 25 March, 2014 at http://www. censusindia.gov.in/2011census/PCA/PCA_Highlights/pca_highlights_india.html.

Office of the Registrar General and Census Commissioner, India. 2014. Profiles of Adolescents and Youth in India: Rural-Urban Distribution of Adolescents and Youth Population. New Delhi: Office of the Registrar General and Census Commissioner, India.

Pandey, P., S. Goyal and V. Sundararaman. 2009. "Community Participation in Public Schools: Impact of Information Campaigns in Three Indian States." Education Economics, 17(3):355-75

Planning Commission. 2012. Press note on poverty estimates, 2009-10. Accessed on 11 March, 2014 at http:// planningcommission.nic.in/news/press_pov1903.pdf.

Planning Commission. 2013. Twelfth Five Year Plan (2012-2017) Faster, More Inclusive and Sustainable Growth, Volume I. New Delhi: Sage Publications.

Ministry of Law and Justice. 2009. The Right of Children to Free and Compulsory Education ACT, 2009. Accessed on 11 July, 2014 at http://mhrd.gov.in/sites/upload_files/mhrd/files/rte.pdf. 


\section{Authors}

K G Santhya, Associate II, Population Council, New Delhi

Shireen J Jejeebhoy, Senior Associate, Population Council, New Delhi

A J Francis Zavier, Senior Programme Officer, Population Council, New Delhi

Rajib Acharya, Associate I, Population Council, New Delhi

Neeta Shah, Project Co-ordinator, CHETNA, Ahmedabad 


\section{List of investigators}

Hetashree Brahmbhatt

Saraswati Chaudhari

Sunanda Chaudhari

Hetal Chauhan

Sangita Chavda

Vijay Dabhi

Tasnim Faruqu

Sangita Gamit

Jyoti Gaur

Ganpat S Gohel

Bhavna Herbha

Padma Kamtilal

Nasim Kousar

Priti Patel Pravin Kumar

Priti Patel Sanjay Kumar

Panna R Lakum

Rekha Parmar

Jinal Patel

Kalpesh Patel

Sharmistha Patel

Nikitaben Dhirajlal Patel

Ruksana Pathon

Megha H Ramanuj

Ashwini Rana

Surekha B Rathwa

Hasmukh Raval

Prakash Kumar Raval

Suresh Revar 

Zone 5A, Ground Floor India Habitat Centre, Lodi Road New Delhi, India 110003 Phone: 91-11-24642901 Email: info.india@popcouncil.org

Ideas. Evidence. Impact. 